\title{
أسلوب الحكيم في القرآن الكريم: دراسة تحليلية بلاغية
}

\author{
Ferki Ahmad Marlion \\ Institut Agama Islam Negeri Batusangkar \\ e-mail: ferkialfateh92@gmail.com
}

\section{Ahmad Dardiri}

UIN Syarif Hidayatullah Jakarta e-mail: ahmaddardiri@uinjkt.ac.id

ملخص: يقوم هذا البحث بتحليل آيات القرآن الكريم التي تتضمن أسلوب

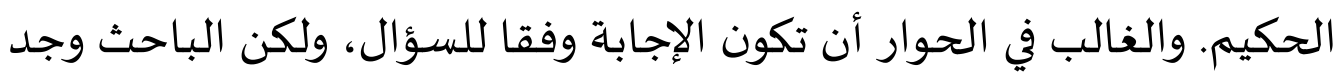

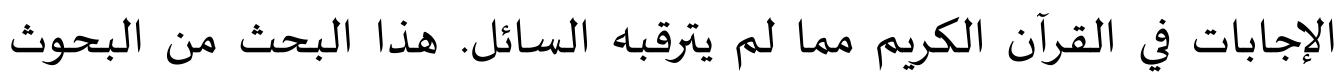
الوصفية. ولأجل ذلك جمع الباحث البيانات من القرآن الكريم والمصيادر

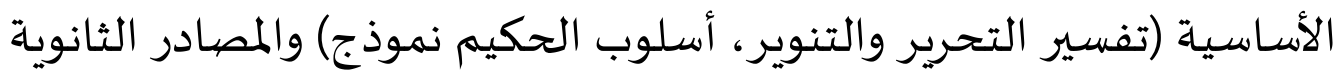

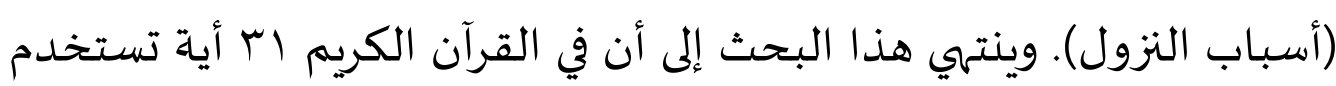

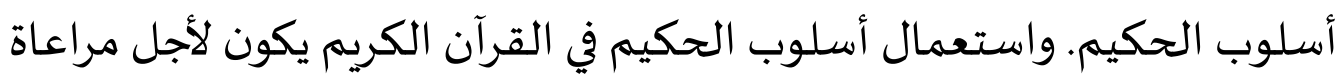

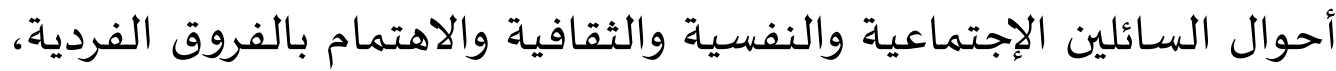

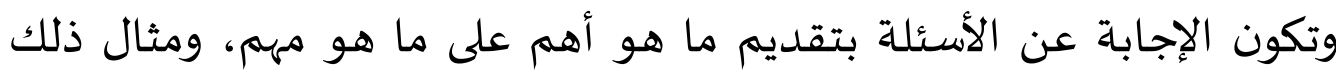

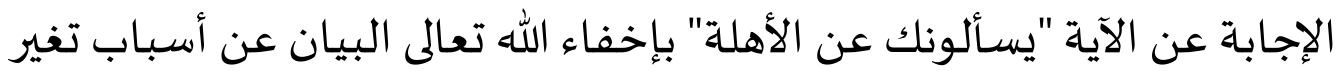

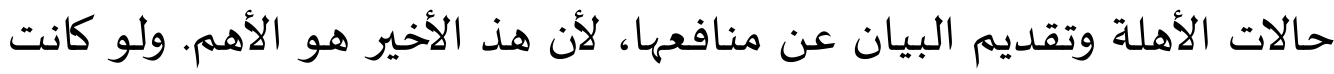

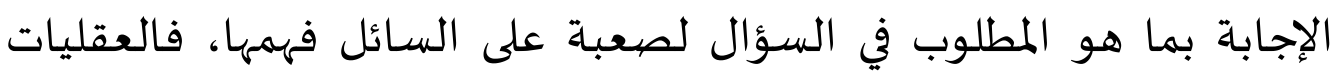
آنذاك كانت بسيطة، والعلوم لم تكن متطورة، فلم تتوفرله القدرة على فهم المابه

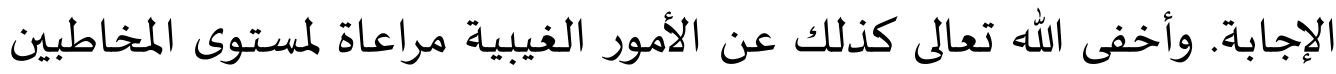
الفكري، ولا فائدة في معرفتها.

$$
\text { الكلمات الأسـاسية: آيات، أسلوب الحكيم، القرآن الكريم }
$$

Abstract: This research is done to reveal the verses of Alquran al Karim which are connected to Uslub al Hakim in Alquran. This is a qualitative research. The data were collected from Alquran and took tafsir at-tabriir wa attanwiir, usluub alhakiin namunaj as the main source 
and asbabun nuzul as the supporting source. The researcher found there are 31 verses which are connected to Uslub al Hakim, the application of Uslub al Hakim in Alquran al Karim to respect and understand who the questioners are, whether it is about social problem, personal or local habits. Uslub al Hakim also concerns on individual difference, and answers the most important and useful questions. For example, the process of moon creation was hidden by Allah SWT because buman being in the era did not have enough capacity to understand it yet. If Allah SWT explains it as they wish, it would be very difficult for them to understand because buman's thinking skill was very simple and there was no proper knowledge to support it yet at that time. Allah SWT also did not explain in detail about the transcendental things, to appreciate thinking capacity and to avoid useless discussion.

Key words: Verses, Uslub al Hakim, Alquran al Karim

والوقوف على أسراره، وجوانب إعجازه ،

المقلدمـة

ومعرفة المنهج القويه والأساليب المثلى

التي سلكها في تلقي المخاطَبين . فهو

معين لا ينضب ، وكنز لا يفنى، ورغم كل

الدراسـات فيه بمختلفة توجهاتها؛ إلا أن الغوص لا يزال مستمرا في أساليبه للكشف عن هذا الجمال المعجز. ولا يخفى على عارف أن القرآن الكريم قد استخدم العديد من الأسـاليب بغيـة التأثير في السـامعين للوصيول إلى أهدافه وتحقيق غاياته ، من ذلك : أسلوب التكرار، وأسلوب التقديم والتأخير ، والذكر والحذف ، والاستفهام والالتفات ...ومنها أسلوب الحكيم. أسلوب الحكيم هو تلقي المخاطب بغير ما يترقبه، ، إما بترك سؤاله والإجابة عن سؤال لم يسأله، وإما بحمل كلاماه على غير ما كان يقصيد، إشـارة إلى أنه كان ينبغي لله أن يسأل هذا

القرآن العظيم معجز من وجوه متعددة من حيث فصاحتاه وبلاغتاه

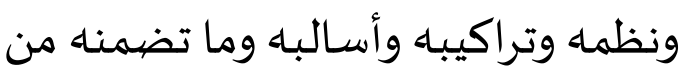
أخبار ماضية ومستقبلة وما اشتمل عليه من أحكام جليـا وقد تحدى ببلاغة ألفاظه فصحاء العرب كما تحداهم بما اشتمل عليه من معان صحيحة كاملة وهي أعظم في التحدي عند كثيرة من العلماء، فأسلوب كلام القرآن لا يشبـا أسلوب كلام رسـول الله. كلام رسـول الله الوارد في أحاديثاء الشريفة لا يقدر أحد

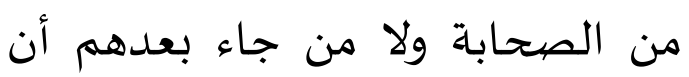
يتكلم بمثل أسـالبـاه في فصاحة وبلاغته

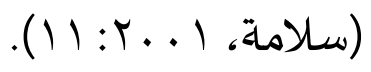
إن دراسـة الأسـاليب القرآنية من خدمة كتاب الله ، وتجلية أوجه العظمة فياه، بإبراز معانياه ، وتجلية مقاصيده، 
العدول لصرف الكلام عن مراد المتكلم إلى معنى آخر يحتمله أيضًا أو بدونها

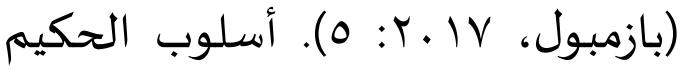
هو فن بديع من فنون الكلام، وضرب من التعبير يقوم على صرف السؤال المتكلم أو كلامه على غير وجهها المراد

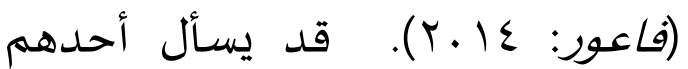
سؤالاً، فتجيبه بغير ما يترقبه إما بترك سؤاله، والإجابة عن سؤال لم يسأله، وإما بحمل كلامه على غير ما كان

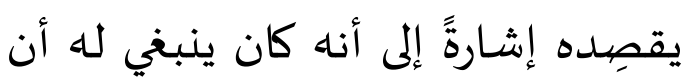
يسأل هذا السؤال، أو يقصيد هذا إنال

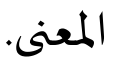

الحقيقة، يجب أن تكون الإجابة

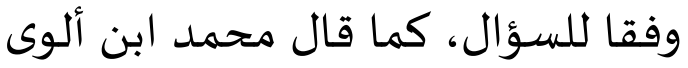
الملكى في زبدة الإتقان في علوم القرآن

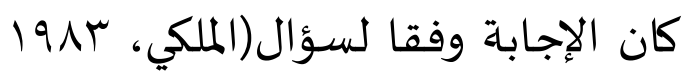
: آ ())، وكذلك قال مناء خليل القطان: في مباحث في علوم القرآن. و قال جلال حلايل التان الدين عبد الرحمن بن أبي بكر السيوطي الأصل في الجواب أن يكون مطابقا للسؤال، إذا كان السؤال متوجها ، وقد يعدل في الجواب عما يقتضيه السؤال ، تنبيها على أنه كان من

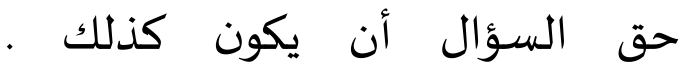
ويسمياء السكاكي :الأسلوب الحكيم. لحوب.
السؤال، أو يقصد هذا لمعنى

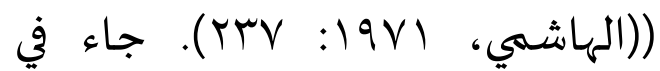

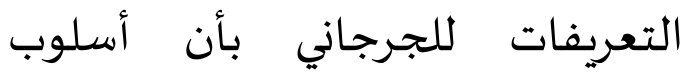
الحكيم : هو عبارة عن ذكر الأهم تعريضا للمتكلم على تركه الأهم

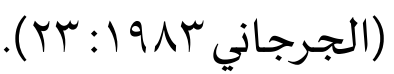
أسلوب الحكيم عند أهل الهل

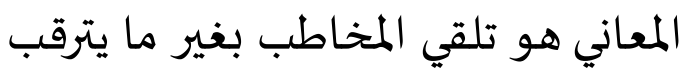
بحمل كلامه على خلاف مراده تنبيها له

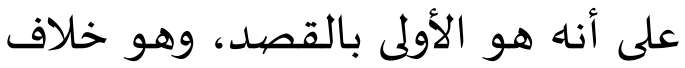
مقتضى الظاهر. وفي اصطلاحات

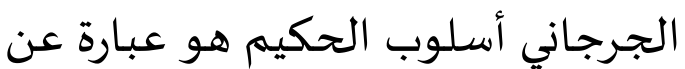
ذكر الأهم تعريضيا للمتكلم على تركه للأهم. أسلوب الحكيم يقوم على مراعاة مقتضى الحال، بخروج الكلام عن

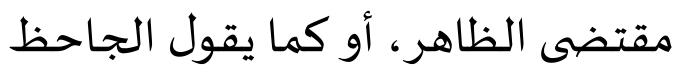

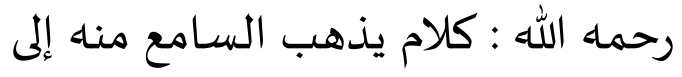
معاني أهله، وإلى قصيد صاحباه. وهو من ين أول من أشـار إلى هذا النوع البلاغي ولكنها إشارة تناسب أوليته يكتنفها من الغموض ما هو الشأن في أوليات الأشياء التي لما تستبن بعد قال ابن كمال باشا

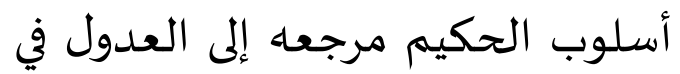
الجواب عن موجب الخطاب لحكمة شريفة يقتضيها المقام، أو نكتة لطيفة

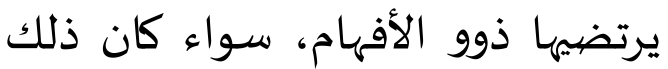


الخمر والميسر فإنهما مذهبة للعقل مسلبة للمال، فأنزل الله تعالى هذه الآية (النيسابوري، ع 199: مV).

قال السعدى: أي يسألك يا أيها

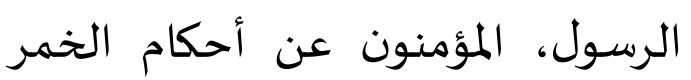

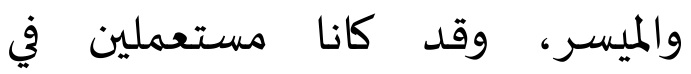
الجاهلية وأول الإسلام، فكأنه وقع فيهما

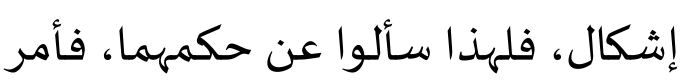

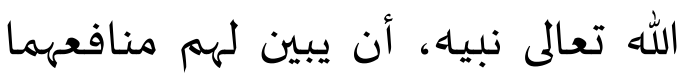

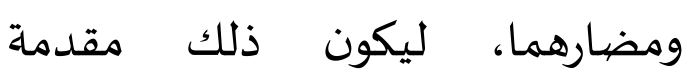
لتحريمهما، وتحتيم تركهما. فأخبر أن

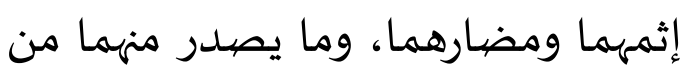

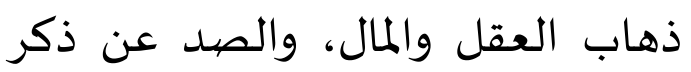
الله، وعن الصلاة، والعداوة، والبغضياء

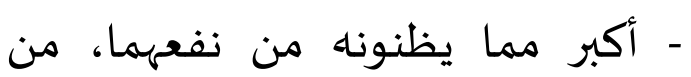
كسب المال بالتجارة بالخمر، وتحصيله

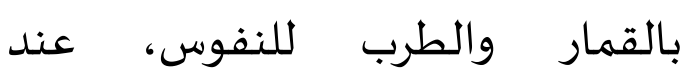
تعاطيهما، وكان هذا البيان زاجرا

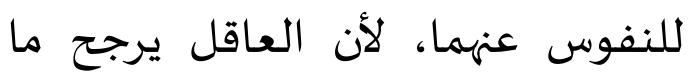
ترجحت مصلحته، ويجتنب ما ترجحت

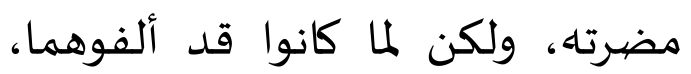
وصعب التحتيم بتركهما أول وهلة، قدم لمان هذه الآية، مقدمة للتحريم، الذي ذكره

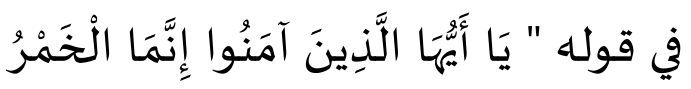

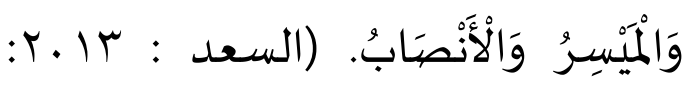
. (ro9
وإنما هو شيء آخر في القرآن، وجد

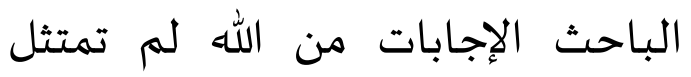

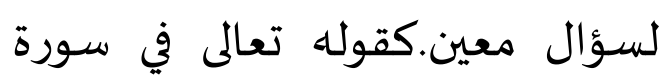

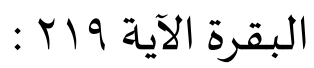

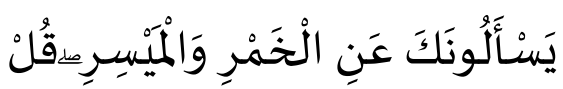

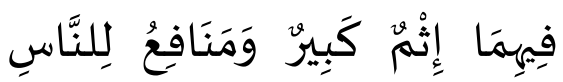

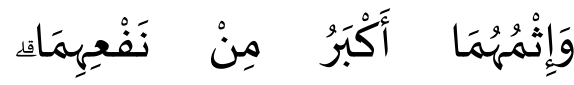

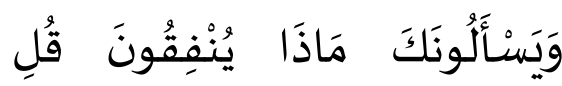

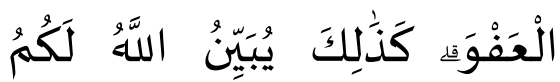

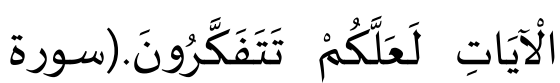

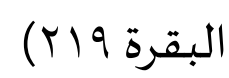
نظر الباحث هذه الآية هي الآية الكريمة يسمى في علم البلاغة وفن

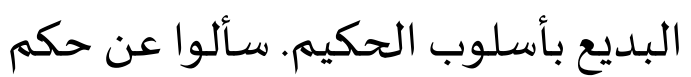

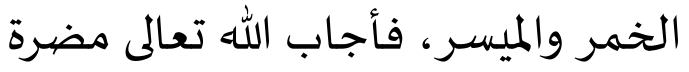

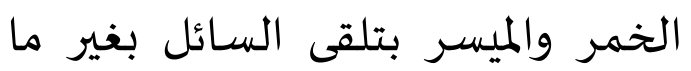
يطلب. فأجاب الله تعالى بالمضرة والنفعة الخمر والميسر لأنه الله تعالى لهالى بالهره عالم بأحوال العبادة، إن الله لم تنزل حكم تحريم الخمر مباشرة، بل إتظر

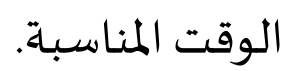
إن كان سبب النزول هذه الآية، كما ذكر أبي حسن علي في أسباب النزول: نزلت في عمر بن الخطاب ومعاذ إذ بن جبل ونفر من الأنصيار أتوا رسول الله صلى الله عليه وسلم، فقالوا: أفتنا في 
إجابة بما لا يرتقيب و لا يتوفق بسؤال.

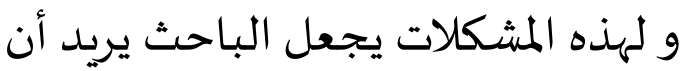

يبحث هذا البحث.

طريقــة البحث هد لبحث

قام الباحث بوسيلة جمع

البيانات بمنهج الإستكشاف بنسبة إلى

نوع البحث كما سبق ذكره، أما البيانات

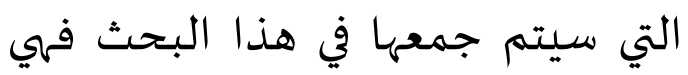

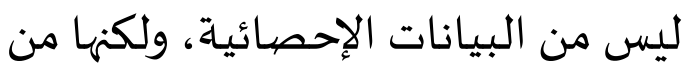

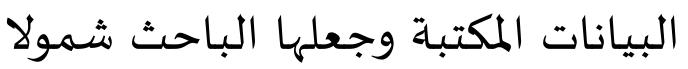
بتوسيع مصادر البيانات التي تنطوي علي مجموعاة من موادة القراءة التي تتعلق بموضوع البحث. وبالإضافة إلى مني ذلك يقوم الباحث بترتيب البيانات وفقا

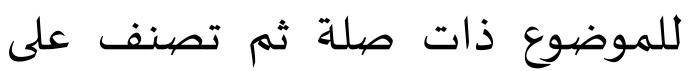
أساس القيمة والجودة الأهمية للمزضوع البحث التي تجري دراستها من

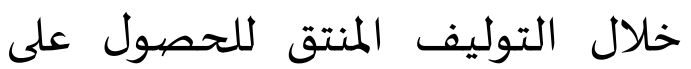
المفاهيم النظرية من تطوير النظريات المختلفة.

أما طريقة التى إستعملها الباحث

في هذا بحث هي طريقة الوصفية باستعمال مداخل الكيفية، وطريقة جمع البيانات بإستعمال الوصفية . تجمع الباحث البيانات بطريقة المراقبة، وقرأءة الكتب المتعلقة بالموضوع
ما جاء في الحديث النبوي

الشريف ، عن عائشة أم المؤونين رضي المايت النيوي

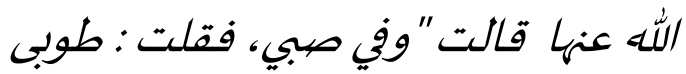
له عصفور من عصافير الجنة، فقال رسول الله صلى الله عليه وسلهم: أَوَلا تلدرين أن الله خلق الجنة وخلق النار، النها فخلق لهنده أهلا ولهنده أهلا ". فكانت رضي الله عنها ت تلوقع

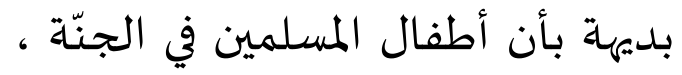

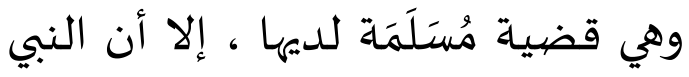
عليه الصلاة والسلام تلقاها بغير ما كانت تتوقع وتحتسب ، وبغير ما كانت تترقب ، فحمل كلامها بخلاف مرادها ، فعدل بالكلام عن مقتضى الظاهر الذي يقتضي أن هؤلاء الأولاد من أهل الجناة، ولم يعملوا ما يستوجب أخراجهم من هن اهن الجنّة، وأحالها إلى أن هذا من علم الهـ الله

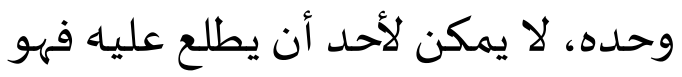
من الغيب المستور، وبهذا (نها عن لهن المسارع إلى القطع من غير أن يكون

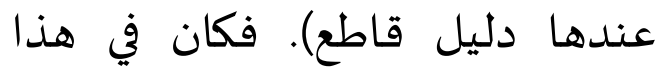
العدول تنبيها لها على أنه كان الأولى هلى بحالها في مثل هذه المسائل الغيبية هو

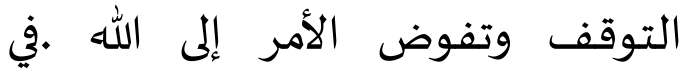
الحقيقة، يجيب أن تكون كل إجابة

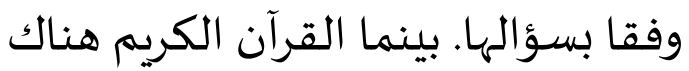




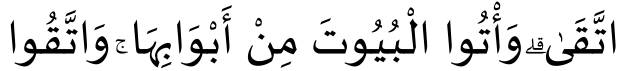

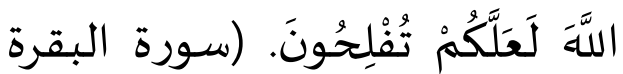
.$(119$

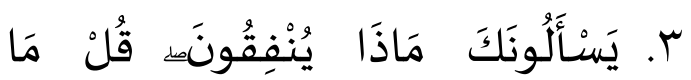

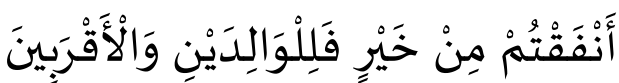

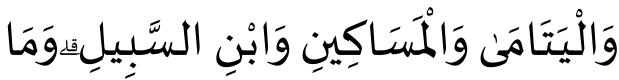

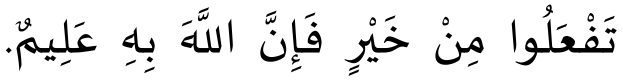

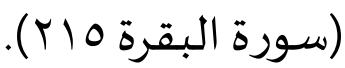

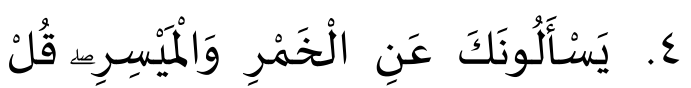

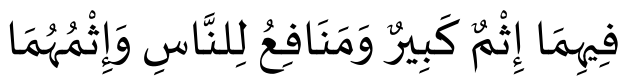

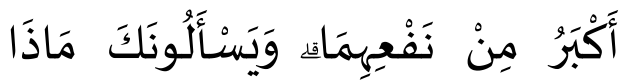

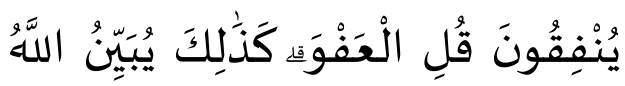

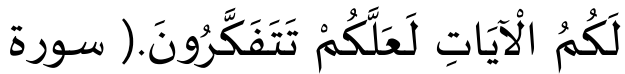

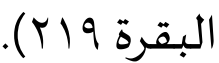

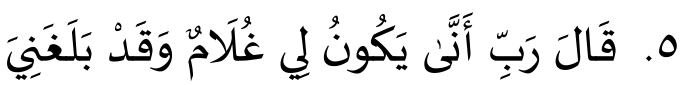

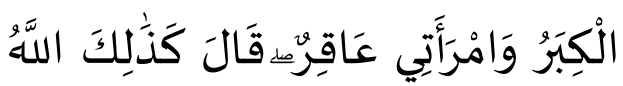

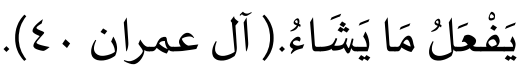

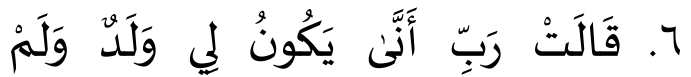

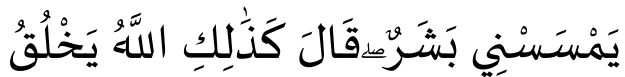

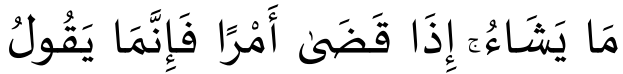

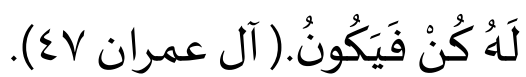

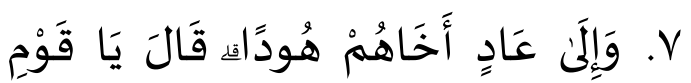

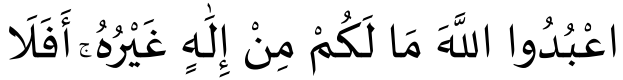

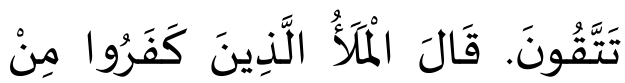

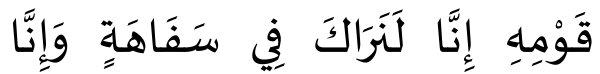

ومصيادر البينات الأيات التى فيها أسلوب الحكيم في القرآن الكريم من سورة الفاتحة إلى سورة الناس. طريقة تحليل البيانات من هذا البحث هى تحليل بلاغى .وهذا التحليل الكتب بناء على

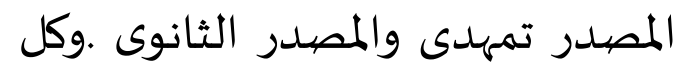
بيانات تصيدر من الكتب التى تتعلق

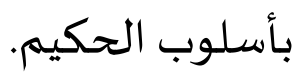
نتائسجِج البحث القرآن الكريم فياه ستة الف وست مائة وست وستين آية، ومائة وأربع

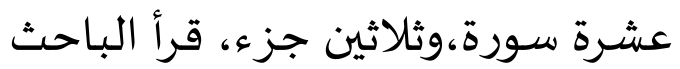
تلك الآيات جميعها واطلعت عليها آية بعد آية، وجد الباحث أن في القرآن الكريم يشتمل على أسلوب الحكيم.أما الآيات كلها فكما يلى:

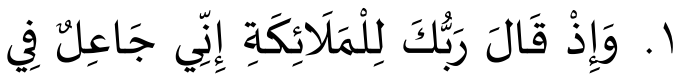

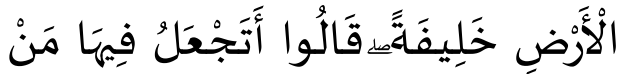

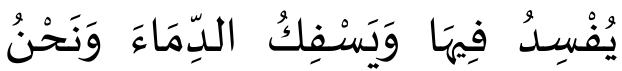

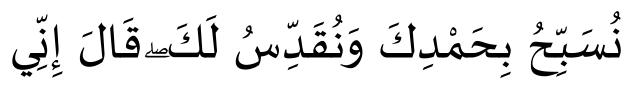

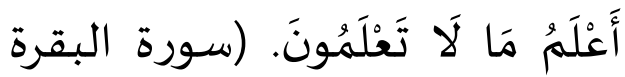

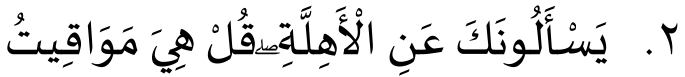

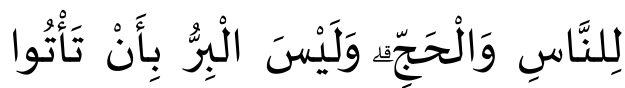

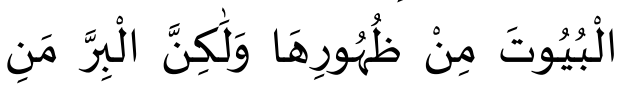




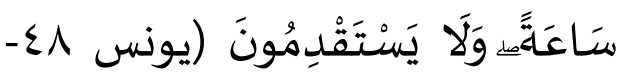

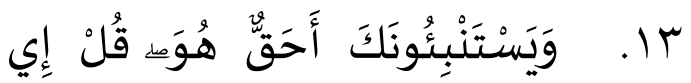

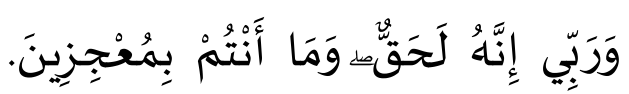

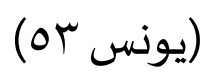

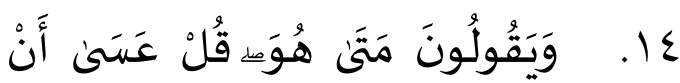

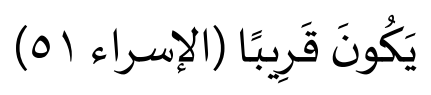

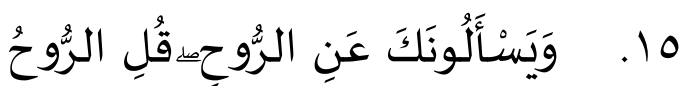

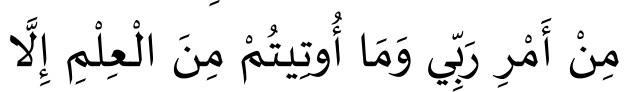

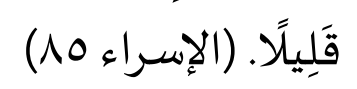

17

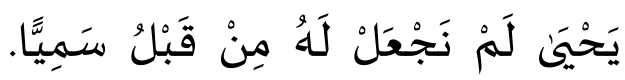

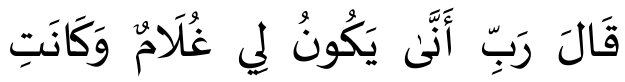

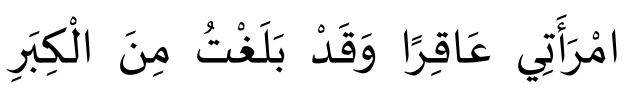

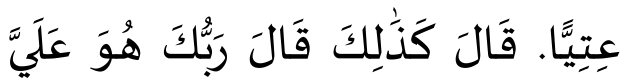

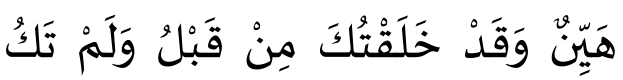

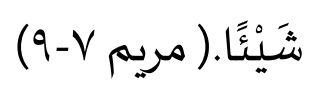

lV

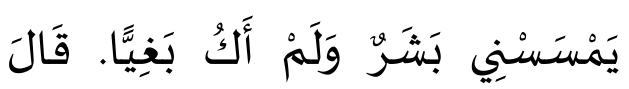

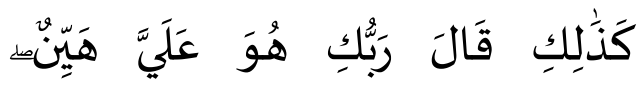

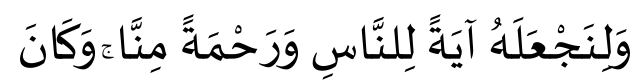

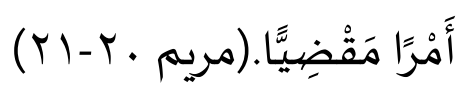

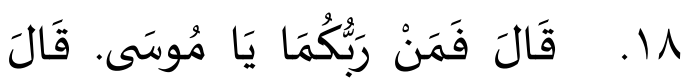

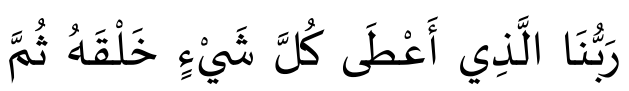

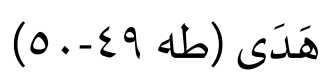

لَنَظُُْْكَ مِنَ الْكَاذِبِينَ. (الأعراف 70-

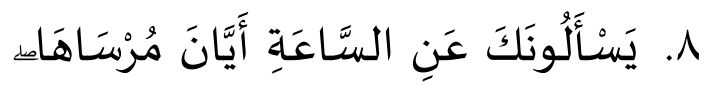

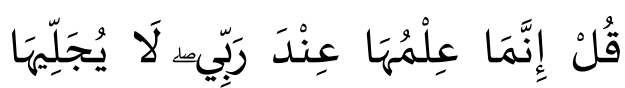

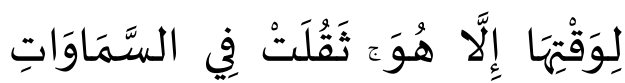

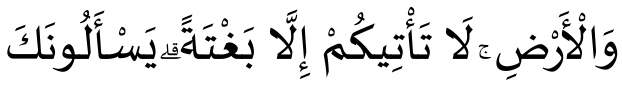

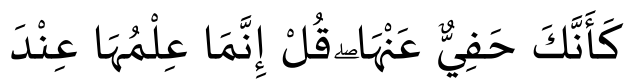

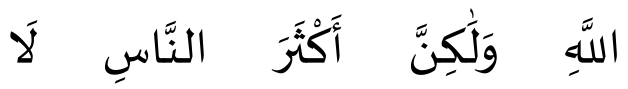

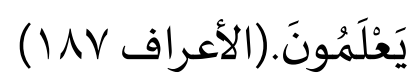

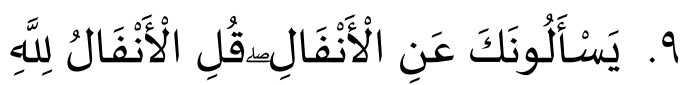

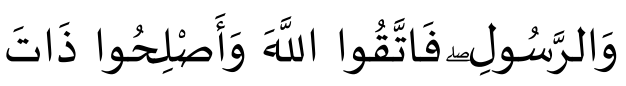

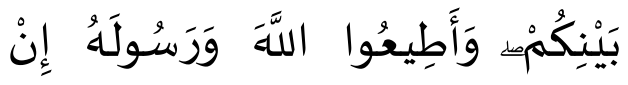

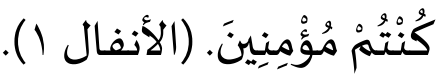

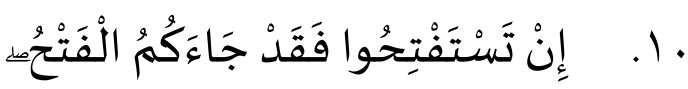

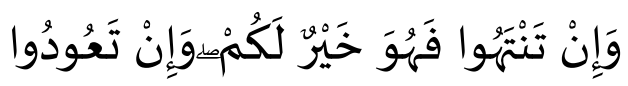

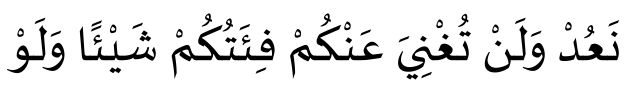

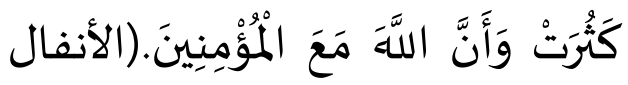

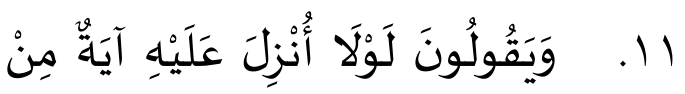

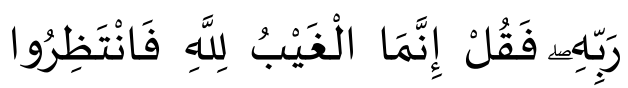

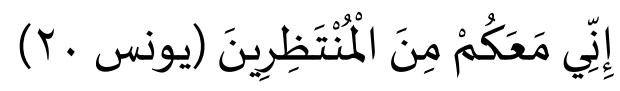

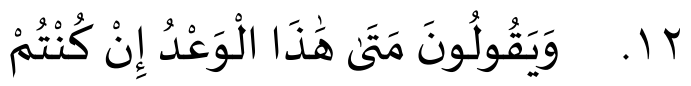

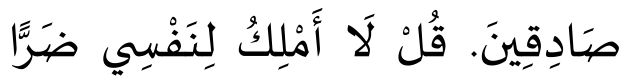

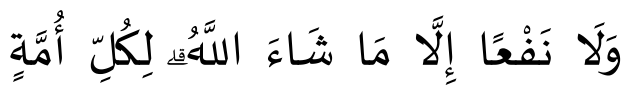

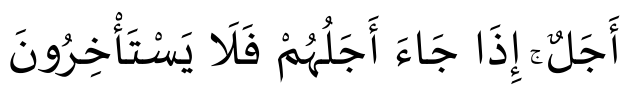




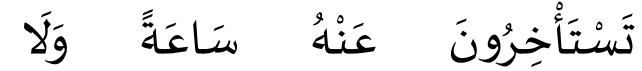

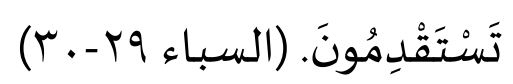

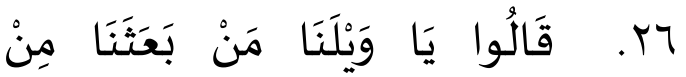

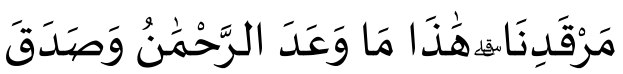

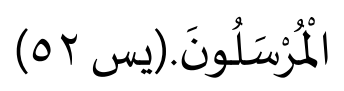

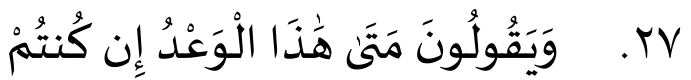

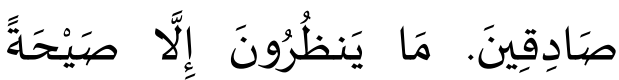

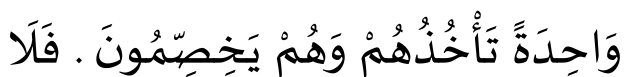

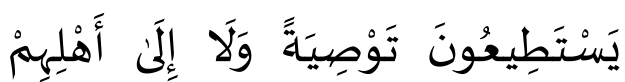

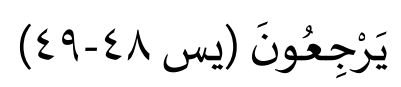

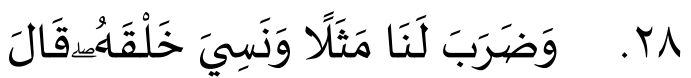

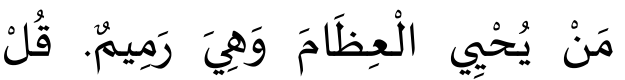

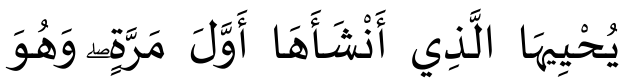

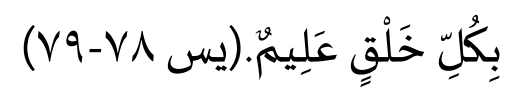

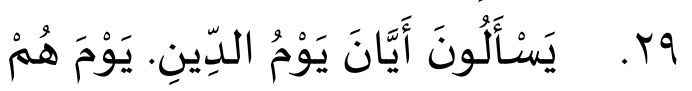

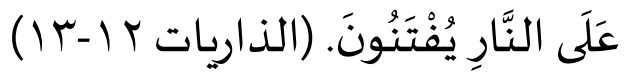

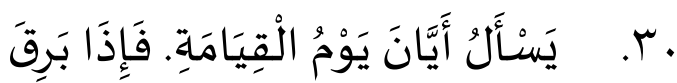

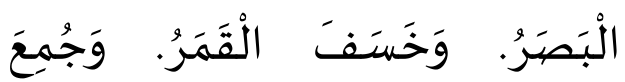
الشَّمْسُ وَالْقَمَرُ يَقُولُ الْالِنْسَانُ

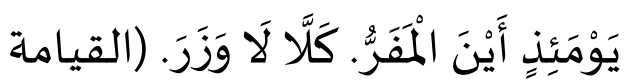

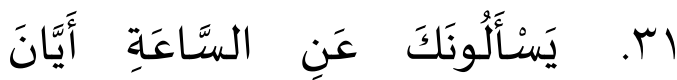

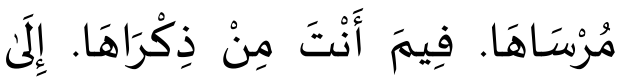

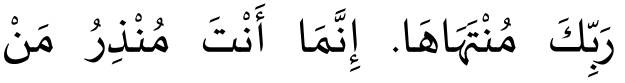

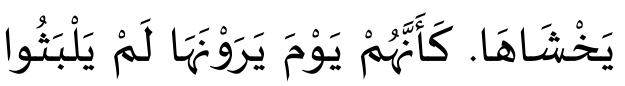

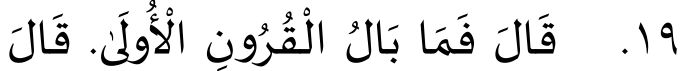

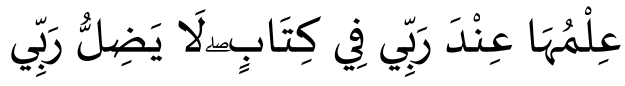

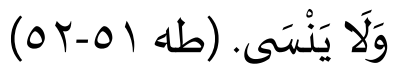

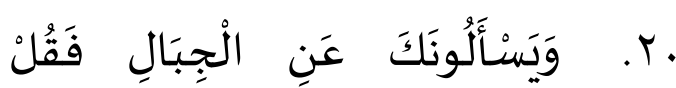

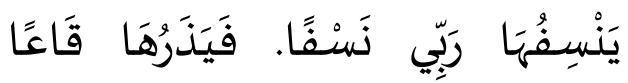

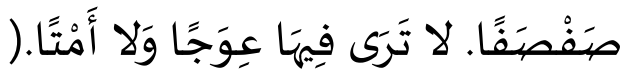
(1.0 ط ط

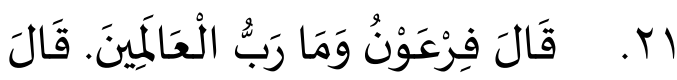

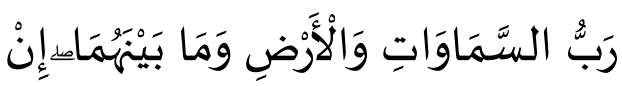

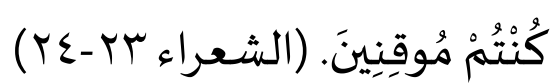

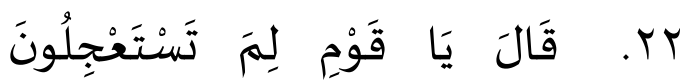

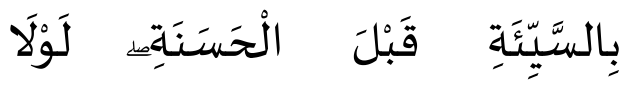

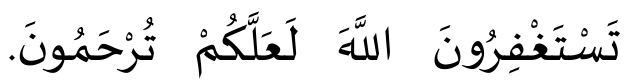

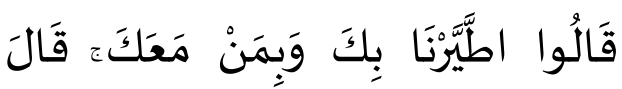

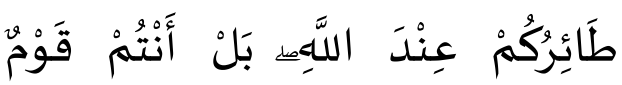

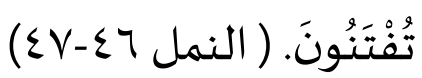

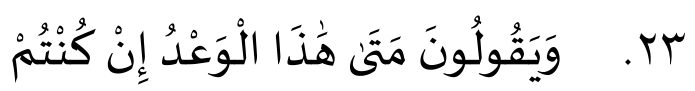

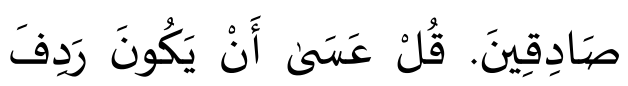
لَكُمْ بَعْضُ الَّذِي تَسْتَعْجِلُونَ. (النمل (VY-Y)

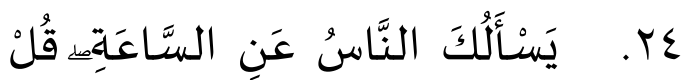

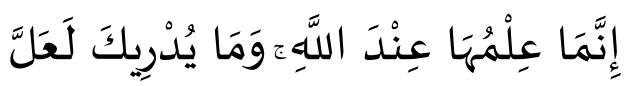

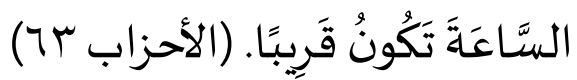

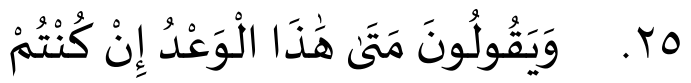

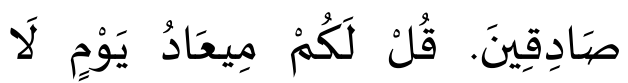


1. الإجابة بما فيه فائدة المخاطب أو

$$
\text { تحقيق الحكمة : }
$$

يظهر هذا الغرض عندما

يكون لفظ السؤال محتملاً للسؤال عن السبب وعن الحكمة، فإن كانوا سألوا عن السبب فقد أُجيبوا بما هو أنفع لهم مما سألوا عناه. وفي هذا دلالة على مناحي التفكير عند

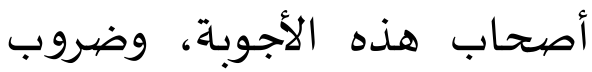
فلسفتهم وقيمهم العقلية والأخلاقية

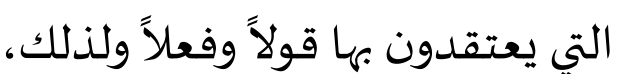
فإن بروز الحكمة فيها يجعلنا نسوغ لأنفسنا أن نصنفه ضمن أدب إنها الحكمة أو على الأقل يقترب من أدب ان الحكمة أو الأمثال "فالحكمة" كلام موافق للحق، وهي عصارة خبرة في الحياة، وخلاصية فهم لأسرارها .أما آيات التي جاء أسلوب الحكيم بهذا وخلاها

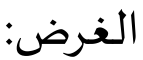

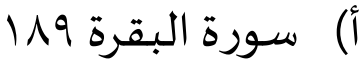
أما أسلوب الحكيم في هذه الأية هو لفظ يَسنَأَلْونَكَ عَنِن الأهِلَّةِة قُلْ هِيَ مَوَاقِيتُ لِلِنَّاسِ

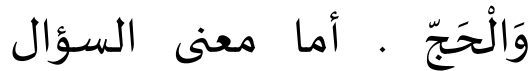

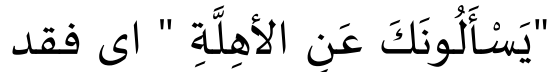
سألوا رسول الله صلى لله عليه الله اله

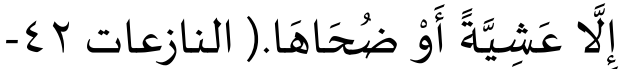

تحليل الآيات التى تتضمنه أسلوب الحكيم من حيث أغراضها.

قسم الباحث تحليل الآيات التى هئل

تتضمنه أسلوب الحكيم من حيث أغراضها وفرق الباحث أغراض أسلوب ابنه الحكيم إلى فصلين، وهما أغراض اساسية و أغراض ثناوية. إذا أغراض وهما اعراصن أساسية هي الإجابة بما فياء فائدة المخاطب أو تحقيق الحكمة. فرق المقاب

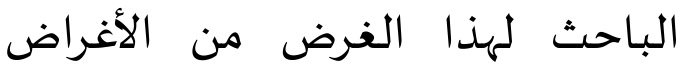
الأخر، لأن هذا الغرض لا تكاد تجد متحدثا عن أسلوب الحكيم إلا وأشـار إليه، لكن لا يتحدثون عنه كغرض بلاغي، بل يجعله البعض من صميم التعريف، والبعض يجعله من الشرح والتوضيح، كما سبق وأن بيّنا ذلك في التعريف الاصطلاحي، ونحن هنا نضعاه في مكانه اللائق باه كغرض مهم من أغرض هذا الفن البديعي، و كتب الباحث هذا الغرض في الباب الثالث.

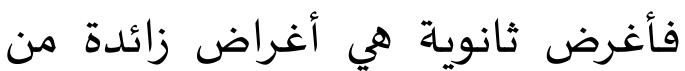

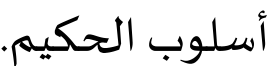


البشرية، ولا تفيدها كثرا في

المهمة الأولى التي جاء القرآن من

أجلها. وليس مجالها على أية

حال هو القرآن. إذ القرآن قد ولد

جاء لما هو هو أكبر من إد تلك

المعلومات الجزئية (سيد قطب :

. ( r. 1$)$

فاللائق بهم أن يتعلموا

المواقيت فهم بحاجة إلهها في

عباداتهم، ولذا جاء الجواب بغير

ما يتطلبون وبخلاف سؤالهم

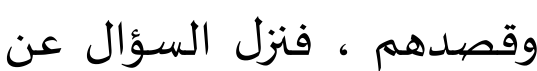

أحوال الهلال منزلة السؤال عن فئن السؤ عن

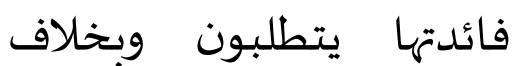
سؤالهم وقصيدهم ، فنزلئ ونيون السؤال عن أحوال الهلال منزلة

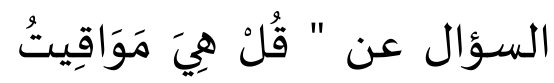
لِلنَّاسِ وَالْحَجِّ".هذا ما يقتضِيها

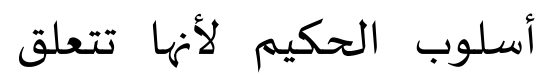

بالمواقيت والحج والمقام مناسب

لها ، وهو أن حقيقة البر تقوى

الله تعالى وليس اجتناب دخول

البيوت من أبوابها أثناء الإحرام.

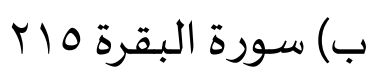

أسلوب الحكيم في هذه

الأية هو لفظ يَسنأَلُونَكَ مَاذَا
وسلم عن الهلال لم يبدو صغيرا

مثل الخيط ثم يعظم ويستدير ثم ينقص ويدق حتى يعود كما

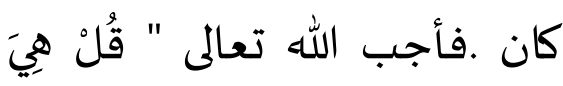

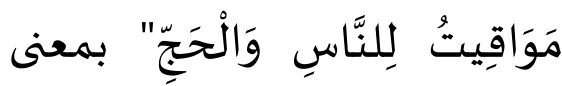
فقل لهم يا محمد إنها أوقات

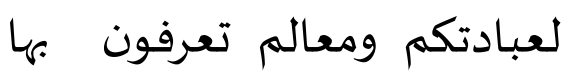
مواعد الصهوم والحج والزكاة . فصرفهم إلى بيان الحكمة من فوان الأهِلَّةِ وكأنها يقول كان الأولى بكم أن تسألوا عن حكمة خلق الأهِلَّةِ لا عن سبب تزايدها في أول الشهر وتناقصها في اخر. والإجابة" العلمية " عن هذا السؤال ربما كانت تمنح السائلين علما نظريا في الفلك، إذا هم اسطاعوا، بما كان لديهم من معلومات قليلة في ذلك إدمان الحين، أن يستوعبوا هذا العلم، معنات

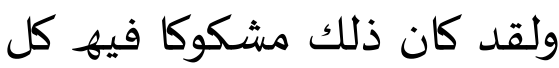

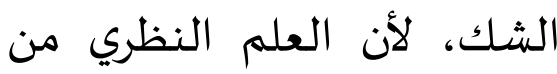

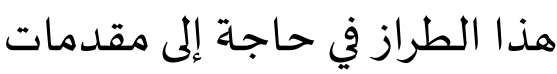
طويلة ، كانت تعد بالقياس إلى هاجلى عقلية العالم كل في ذلك الزمان

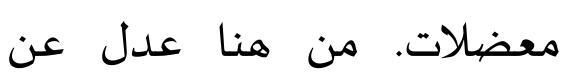

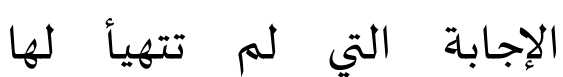


والخمر والميسر، فأجاب الله

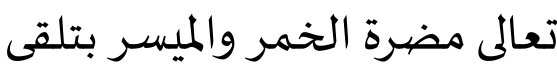
السائل بغير ما يطلب. فأجاب الله تعالى بالمضرة والنفعة الخمر لمعر لهابر

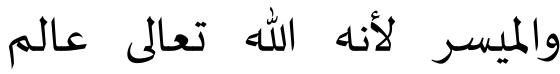
بأحوال العبادة، إن الله لم تنزل لهانه حكم تحريم الخمر مباشرة، بل إتظر الوقت المناسبـة. د) يس Vو

نظرنا، حرف الإستفهام

في هذا الأسلوب هو "من". و عرفنا تستعمل للعقلاء، نقول هن

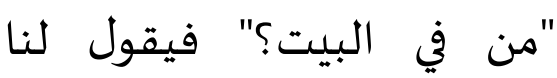
"فلان" أو "من حرر فلستين من الن الصليبين؟" فيقول "صلاح الدين". وذهب السكاكى إلى أنه

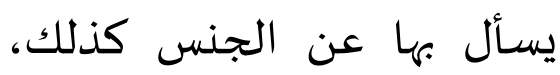

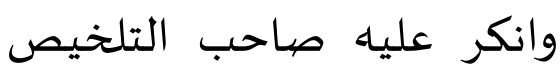
هذا، واستـدل السكاكى بقول القريش "من يحي العظام وهي رميم". أي هذه الجملة ليستفهم

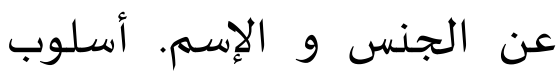
الحكيم في هذه آية هو الإسيم اسلون الإستفهام عن من يجي العظام وهي رميم؟ فأجاب الله تعالى قُلْ لُّن

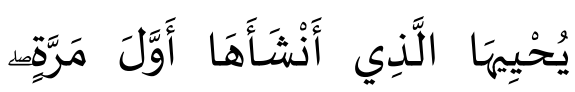

يُنْفِقُونَ قُلْ مَا أَنْفَقْتُمْ مِنْ خَيْرِ

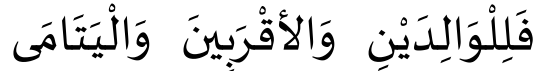
وَالْمَسَاكِينِ وَابْنِ السَّبِيلِِ . أما

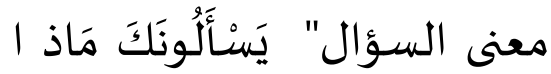

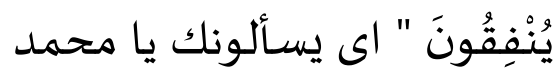
ماذا ينفقون وعلى من ينفقون؟ بأي وقد نزلت لما قال بعض الصحابة

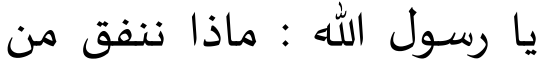
أموالنا وأين نضعها؟ فأجب الله

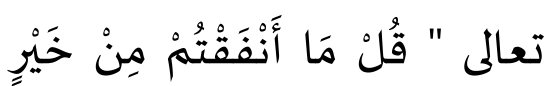

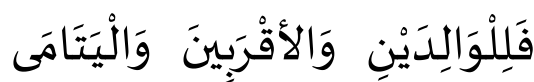

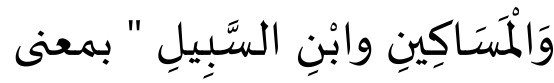
قل لهم يا محمد اصرئِ هذه الوجوه. أجيبوا ببيان المصرف، قلت : قد تضهمن قوله اجهيوان

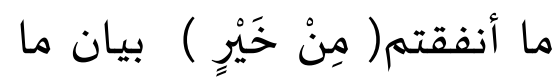
ينفقونه وهو كل خير وبنى الكلام على هو اهم وهو بيان الصرف لأن نفقه لا يعتد بها الا أن تقع وهو بيان الهرق موقعها. تنبيها على أن هذا هو الأولى والأجدار بالسؤال عنده.

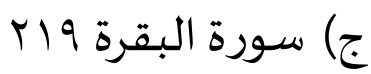
نظر الباحث في هذه الآية هي الآية الكريمة يسمى في علم

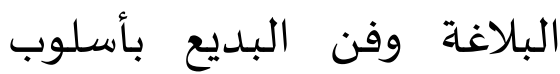
الحكيم. سألوا عن حكم الخمر الباعر باسعو 
ليسألوه عن كيفية تقسيمها، ولمن هي أللمهاجرين أم للأنصار؟ لمهيه وما هو الأنفال وعلمه؟، وكان مقتضى الجواب العادي أن يقول تقسيمها كذا ويحدد الكيفية في التقسيم، ويقول للمهاجرين أو للأنصار أو لهما جميعا، لكن عدل في الجواب وكان بخلاف مرادهم وبغير ما لتهن يتطلبون وعلى غير ما يترقبون

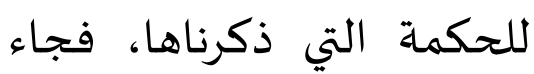
الجواب أن يقول لهم بأن حكمها

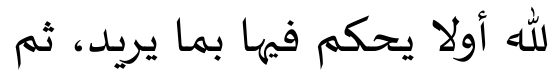
للرسول يقسمها بينكم كما أمر

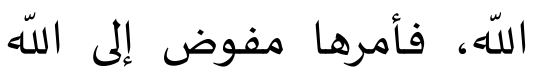
ورسوله، من غير أن يدخل فيه رأي أحد منكم، ثم زاد في الإفـادة بما يقتضياه الأولى والأهم لحالهم ألهم بأن يتقوا الله ويصلحوا ذات بينهم. ونظر الباحث هذه آية هي من أسلوب الحكيم تلقي السائل بغير ما يتطلب لتنبيه علي اللائق

$$
\begin{aligned}
& \text { والأهم. }
\end{aligned}
$$

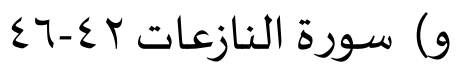

فأسلوب الحكيم في هذه

آية في الفظ أو السؤال
وَهُوَ بِكُكِِّ خَلْقِ عَلِيمُ. وجواب العلمية من هذا السؤال هو الله.

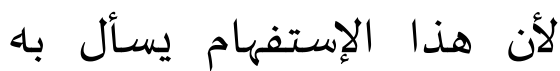

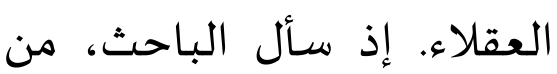
يذهب إى القاهره؟ فأجاب إد الداب الصحيحة والعلمية من الذي باه العقلاء كا إسم الناس. أما في

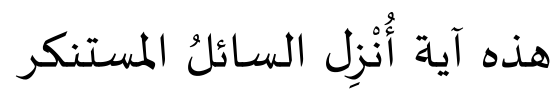

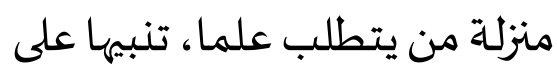

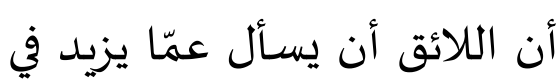
إيمانه، بدل أن يستحيل وقوع إن إنسال

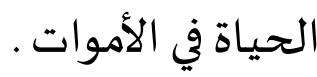
هورة سورالأنفال الاموات

أسلوب الحكيم في هذه المنها

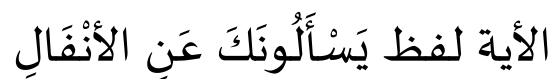

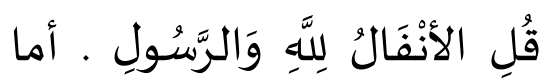
معنى السؤال " يَسنَأَلْونَكَ عَنِ الأنْفَالِ" أى يسألونك أصحوابك

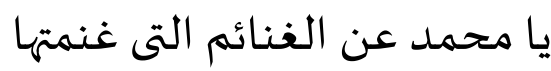

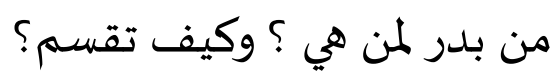

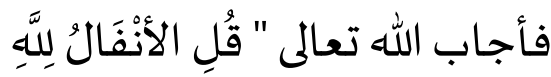

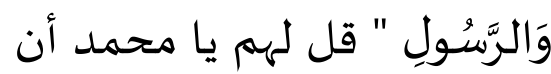

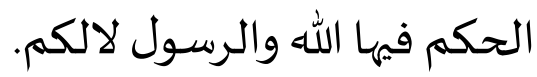
فهذه الآية نزلت حين اختلف المقاتلون في توزيع غنائم بدر، فذهبوا إلى رسول الله 
وقد ورد لله استفهام بحرف

"من" فأتى موسى بالصفات الله.

عرفنا أن الله يغلب آيات التي باتئ

كانت على طريقة أسلوب الحكيم

تقدم مسند إلياه. ومع هذا فإن إن إنان

تقدمه لله أغراض بلاغية منها:

لفت النظر إلى أهميتاه و تعجيل

المسرة و تعجيل المساءة و

التشويق و و التلذيذ بمئ

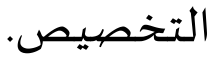

r. إظهار القدرة على الجدال والمحاورة.

هذا جواب يقوم على المنطق

والإقناع العقلي للأشياء، وكأنها

يخاطب العقل أكثر من خطابه

القلب والمشاعر، فهو بذلك يقترب

من فن الإقناع عن طريق تسخير

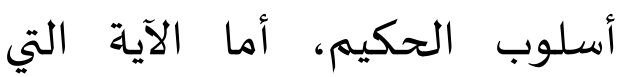

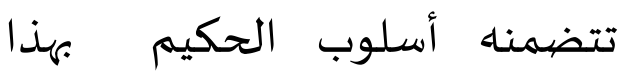

الغرض

$$
\text { أ) سورة البقرة . }
$$

أسلوب الحكيم في هذه

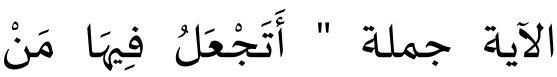

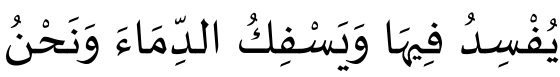

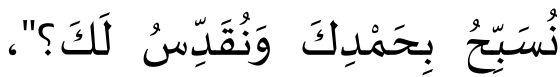

فأجاب الله تعالى للملائكة " إِنّي

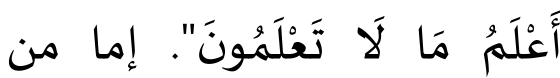

"يسألونك عن الساعة أيان

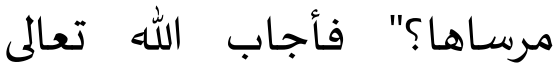
بسؤال فيم أنت من ذكراها؟. السؤال يتطلب المعرفة بوقت

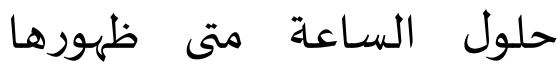
وثبوتها؟، فأجيبوا على طريقة أسلوب الحكيم، بأنه وإن طال تأخر حصولها فإنها واقعة وانهم يوم وقوعها كأنه ما لبثوا في انتظار إلا بعض يوم.

"فِيَمَ أَنَتَ مِن ذِكْرَاهَا . إلى يَلى

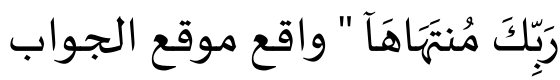

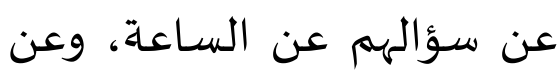
وقت وقوعها. والمقصود بهذا الجواب توبيخهم على إلحاحهم في السؤال عنها، مع أن الأولى بهم إلى توبهم

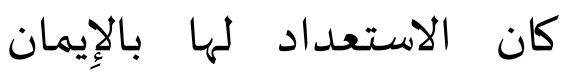

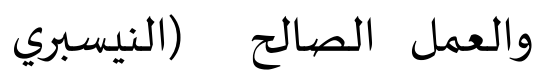
. (r. T. T. T $0 .-\varepsilon q ه$ (j

أسلوب الحكيم في هذه

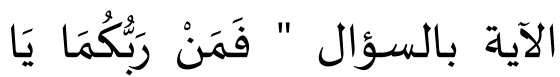
مُوسَى؟" هذا السؤال فرعون لنبي موسى وهارون عليهما

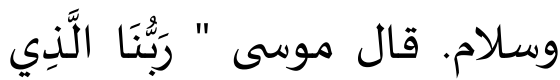

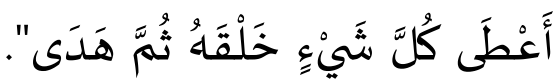


الدماء، فإن كان المراد عبادتك،

فنحن نسبح بحمدك ونقدس لك انك أمراد

، أي : نصلي لك كما سيأتي، أي :

ولا يصدر منا شيء من ذلك،

وهلا وقع الاقتصار علينا ؟ قال

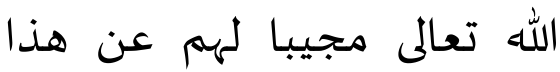

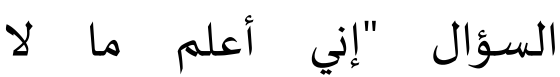

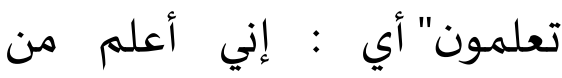

المصلحة الراجحة في خلق هذا

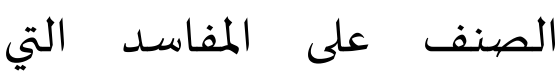

ذكرتموها ما لا تعلمون أنتم ؛

فإني سأجعل فيهم الأنبياء،

وأرسل فيهم الرسل، ويوجد فيهم

الصديقون والشهداء،

والصالحون والعباد، والزهاد

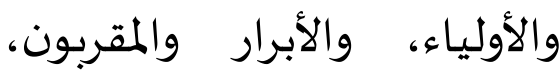

والعلماء العاملون والخاشعون، والابراء والمعربون

والمحبون له تله تبارك وتعاءلى وتهاءلى

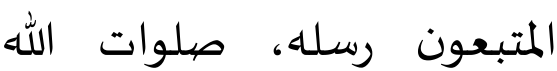

وسلامه عليهم. (إبن كثير: 1999)

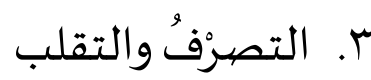

إذا السؤال يتعلق بأمر

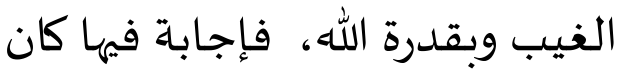

بإرجاع علمها إلى الله تعالى والهدف

من ذلك هو الوصول إلى حقيقة

الإمان بالله تعالى، وإخفاء امر لوهرئ
أحكام الهمزة للتصور يكون

الجواب عنها بتعيين المسؤول عناه من فعل أو فاعل أو غيرها، ولا يصح أن يكون بنعم أو لا.

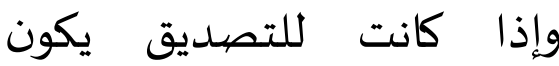
الجوب عنها بنعهم أو لا. كالسؤال

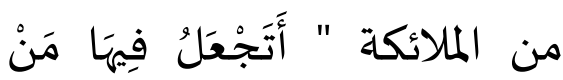

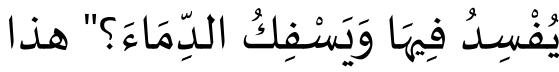

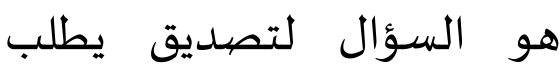

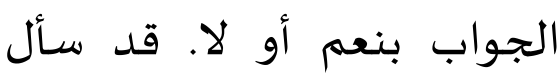
الملائكة عن سبب خلق الإنسان والجواب بتذكير الملائكة بعلم المبل الله المطلاق والله أعلم منهم. فسؤال الملائكة هو سؤال استعلام واتكشاف عن الحكماة، فالله تعالى أجابهم بأنه يعلم ما لا

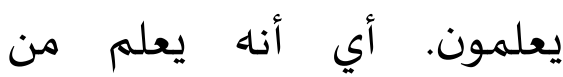
المصلحة الراجحة في خلق هذا

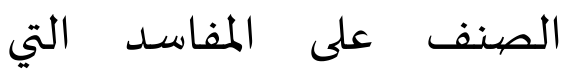

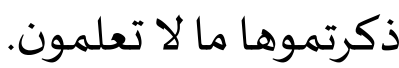

قال عماد الدين إبن كثير

"أتجعل فهها" وإنما هو سؤال

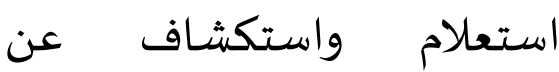
الحكمة في ذلك، يقولون : يا ربنا، ما الحكمة في خلق هؤلاء مع أن منهم من يفسـد في الأرض ويسفك هولك مع اء 
جملة كذلك الله يخلق ما يشئ، نظرنا أن الملك يتصرف من السؤال.

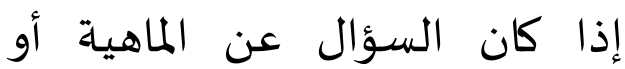
الطريقة أو السبب تعلق بالغيب، كان الجواب ببيان قدرة الله تعالى بالى لهوبه وعلماه مطلق له. وهذا التحليل نظرنا من الجملة "كذلك يخلق ما يشئ وهئ فإن الملك يتصرف من السؤال.

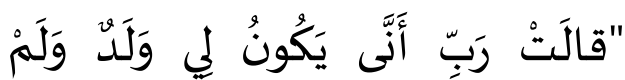

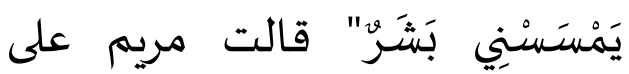
سبيل التعجب والاستغراب: يا رب كيف يكون لي ولد والحال أنى لم

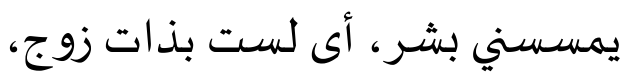
ولم يحصل منى قط ما يكون بين الرجل والمرأة مما يسبب عنده وجود

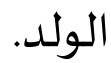

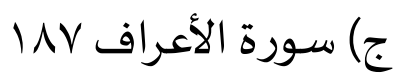
أسلوب الحكيم في هذه الأية

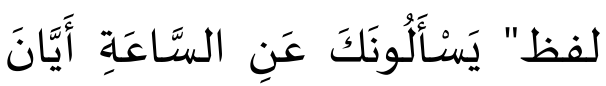

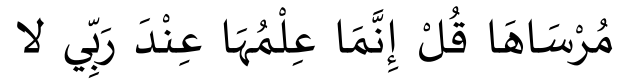

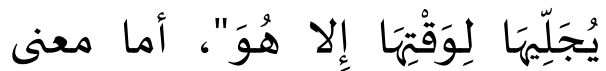

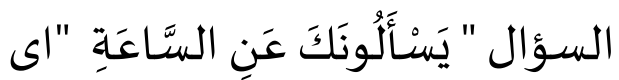

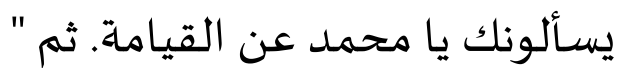

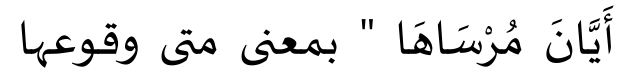
وحدوثها؟، لأن ادات الإستفهام

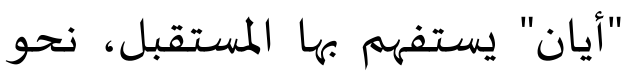

الساعة، وقصر علمها على مالك أمرها سبحانه بت للحذر، وإشفاق في قلوب أهل الشريعة الموقنين بالله واليوم الآخر( محمد أبو موسي:

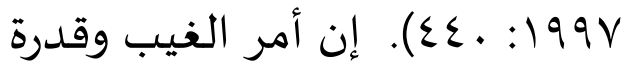
الله علمهما مطلق له ، أما الآيات التي تتضمنه أسلوب الحكيم بهذا

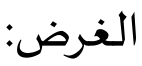

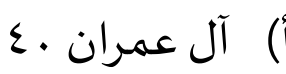

فأسلوب الحكيم في هذه آية

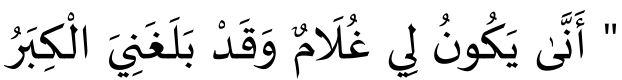

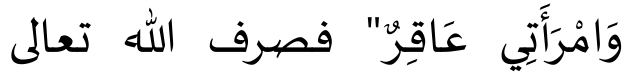
بإِجابة " كَذْلِكَ اللَّهُ يَفْعَلْ مَا يَشَاءُ". نظر الباحث في هذه آية أن السؤال عن كيفية منح الولد والجواب كان بالتذكير بقدرة الله تعالى. فهذه أسلوب الحكيم تلقي السـائل بغير ما بالئ

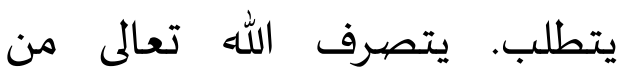
السؤال زكريا لأن السؤال عن أمر تئر

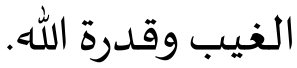

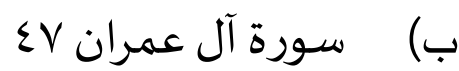
أسلوب الحكيم في هذه آية أني يكون لي ولد ولم يمسسني بشر. فقال الله كذلك الله يخلق ما يشاء.

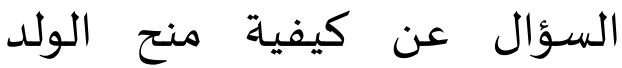
والجواب كان بالتذكير بقدرة الله. في 
رجع الباحث إلى أسباب

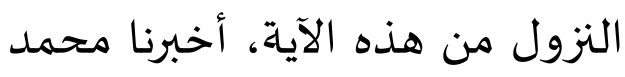

بن عبد الرحمن النحوى، قال: أخبرنا محمد بشر بن العباس، قال:

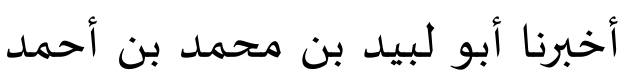
بن بشر، قال: حدثنا سويد، قال: حدثنا على بن مسهر، عن الأعمش بلثر، عن إبراهيم عن علقمة عن عبد الله، قال: إني مع النبي صلى الله عليه وليه وسلم في حرث بالمدينة وهو متكىء على عسيب، فمر بنا ناس من اليهود، فقالوا: سلوه عن الروح. فقال بعضهم: لا تسألوا فيستقبلكم المونم بما تكرهون. فأته نفر منهم، فقالوا: يا أبا القاسم، ما تقول في الروح؟ فسكت ثم ماج، فأمسكت بيدي علي جبهته، فعرفت أنها ينزل عليه، فأنزل

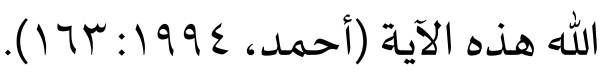
وبهذا أسباب النزول قداهد، عرف الباحث أن السـئل يسألوا الى النبي صلى الله عليه وسلهم عن الروح وتعريف الروح أو حقيقة من الروح. ولكن صرف الله تعالى بغير ما يطلب السائل. وسُؤالههم عن الروح معناه أههم سألوا عن بيان ماهية ما يعبر عند في اللغة العربية بالروح والتي
"أيان يثمر هذا الغرس؟" والجواب بعد سنة و يستعمل في مواضع التفخيم.

نظر الباحث أن في هذه لأية عدل في الجواب بخلاف ما يتطلبون لبيان خطئهم في السؤال عن وقت الساعـة، ثم وجَّهَهُم لما هو أهم وأولى لهي من سؤالهم وهو الاستعداد لها لإنها

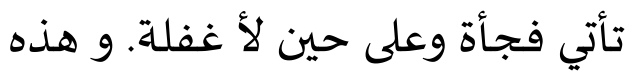
لآية من آيات الأسلوب الآحكيم لأهنا تلقى السائل بغير ما يطلب، صرف

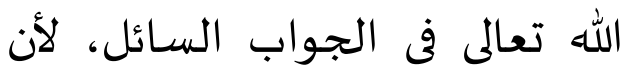

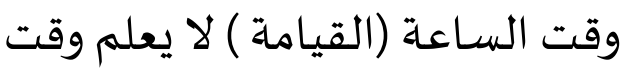

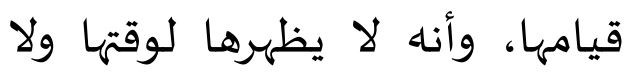
يعلمها غيرُ الله. د) سورة الإسراء 10 أسلوب الحكيم في هذه الأية

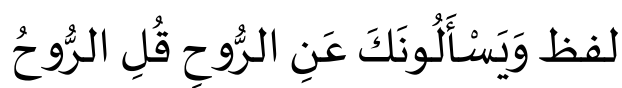

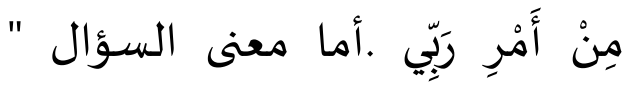

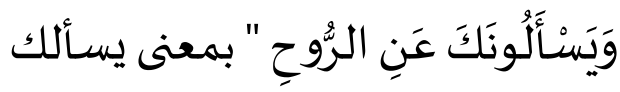

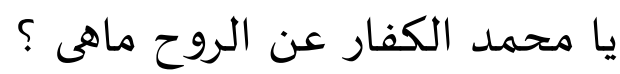

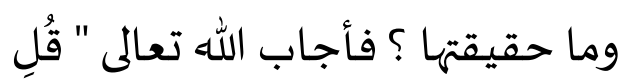

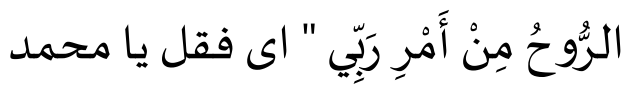

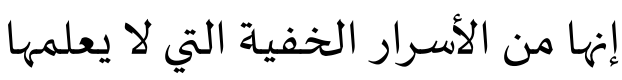
إلا الله. 
الروح وربطها بخالقها ، لذا اقتضت الحكمة سـد طريق معرفتها.

كما قال إبن عاشور : وإنما سألوا عن حقيقة الروح وبيان ماهيتها ، فإنها قد شغلت الفلاسفة وحكماء المتشرعين، لظهور أن في

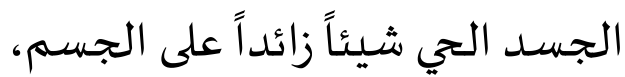

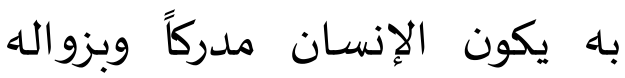
يصير الجسم مسلوبَ الإرادة والإدراك، فعلم بالضرورة أن في النيم الإده

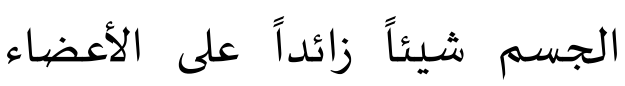

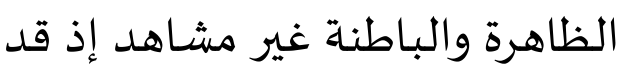
ظهر بالتشريح أن جسم الميت لم يفقد شيئاً من الأعضياء الباطنة التي جاني كانت لله في حال الحياة. وإذ قد كانت عقول الناس قاصرة عن فهم حقيقة الروح وكيفية اتصالها بالبدن وكيفياة انتزاعها منه وفي مصيرها بعد

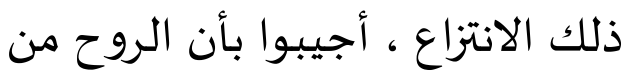
أمر الله ، أي أنه كائن عظيم من اجن النان

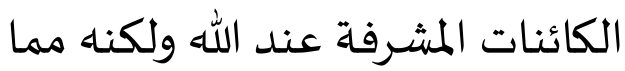
استأثر الله بعلماه. وثانيهما: يعدل عن

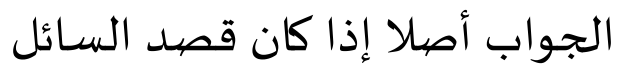

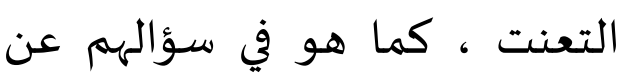
الروح. فالحكمة تقتضي ترك البيان قصد النهي عن السؤال في مثل هذه
يعرف كل أحد بوجه الإجمال أهها

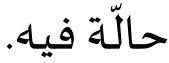
فمن سبب النزول ندرك أن قريشا تسأل تعنتا وتكبرا وإفحأما عن حقيقة الروح وبيان ماهيتها فالروح يعرف كل أحد بوجه

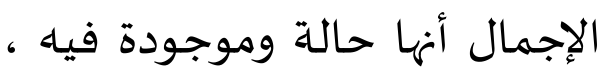
فأُمر النبي صلالله عليه وسلم بأن الأن يجيبهم بخلاف مرادهم ، وعلى غير ما يتطلبون ، فقد سألوا عن الماهية

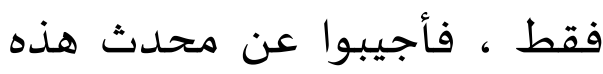
الماهية وعن مقدار علمهه مع علم الله ، وهذا العدول يرجع لسببين

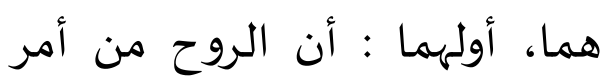
الغيب الذي استأثر الله باه ولم يعلمِ باه أحدا ، فعقول الناس قاصرة عن فهم حقيقة الروح ، وكيفية اتصالها

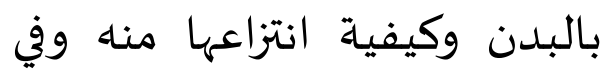
مصيرها بعد ذلك الانتزاع عن فهم حقيقة الروح ، وكيفية اتصالها

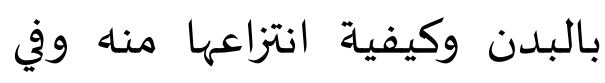
مصيرها بعد ذلك الانتزاع على بلوغه

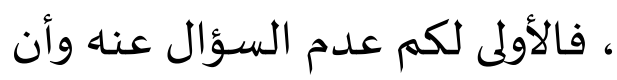
تشتغلوا بما هو أهم مثل الاشتغال

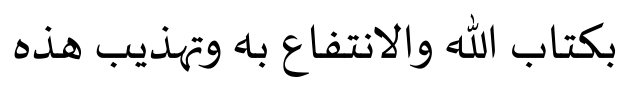




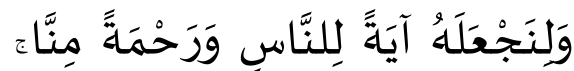

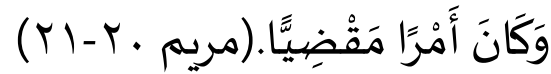

فمريم عليها السلام تسأل

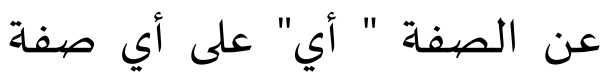

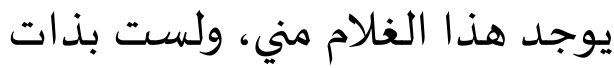

زوج، ولا يتصور مني الفجور فهي لا

تتصور وسيلة أخرى لأن يهبها الله

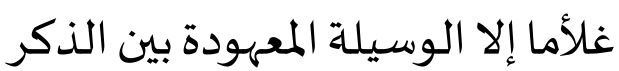

والأنثى، فعُدِل في الجواب من بيان الصفة إلى بيان هون هذا الخلق على الله، ثم استطرد في الزيادة لبيان

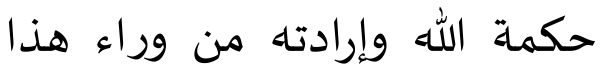
الخلق وصرف الله تعالى في الجوابه

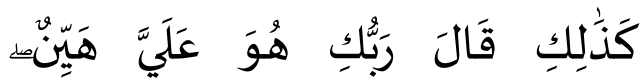

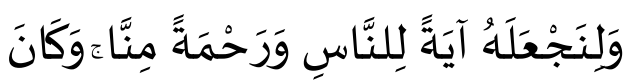

أَمْرًا مَقْضِيًَا.

$$
\text { و) طله .0) }
$$

أسلوب الحكيم في هذه الآية

بجملة الإستهام فَمَا بَالْ الْقُرُونِ

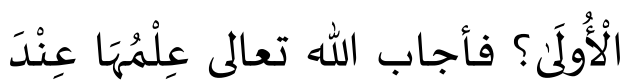

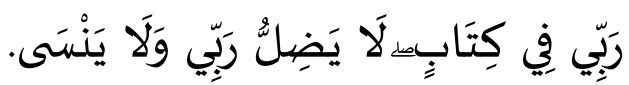

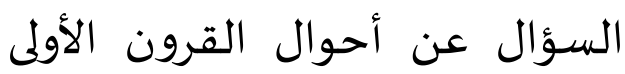
والجواب بذكر أن الله تعالى حافظ الهوال الهرون لأحوالها في كتاب الغيب أو في اللوح

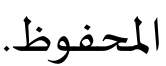

الأمور الغيبية ـ قال الأمام الألوسي:

وهو من أسلوب الحكيم (ابن عاشور، ع (1919: (190). هو) سورة مريم V-P

أسلوب الحكيم في هذه الآية

أني كون لي غلام وكانت امرأتى عاقرا وقد بلفت من الكبر عتيا؟ فأجاب الله تعالى كذالك وقال الله رَبُّكَ هُوَ هَّ

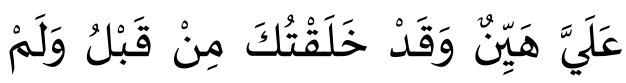
تَكُ شَيْيًْا. نظر الباحث عن هذه الآية عدل ف الجواب من بيان الكيفية إلى بيان هون هذا خلق على الله، ثم إستطرد لبيان تلك السهولة بأن هونان خلقهاه قبل ذلك ولم يكن موجودا، ة

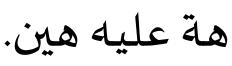

و كذلك في سورة مريم .rا r. في هذه الآية، قد سألت مريم لجبريل عليه السلام، قالت: كيف

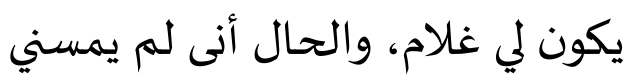
بشر من الرجال عن طريق الزواج

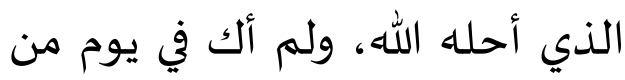
الأيام بغيا.

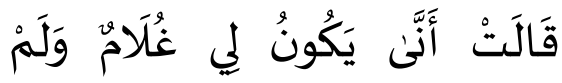

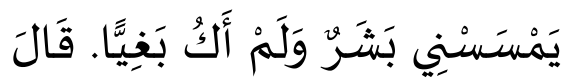

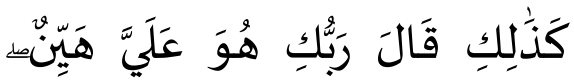


لبيان أهميته تقريعا وتوبيخا على تكذيبهم في الدنيا وبيان هذه آية هي صرف المسؤول الى جواب لا يطلب

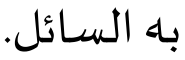

"مَن" استفهام عن فاعل

البعث مستعمل في من التعجّب والتحسّر من حصول البعث . ولما

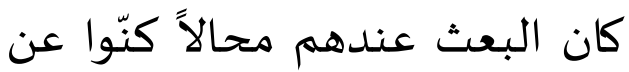
التعجب من حصوله بالتعجب من فاعله لأن الأفعال الغريبة تتوجاء

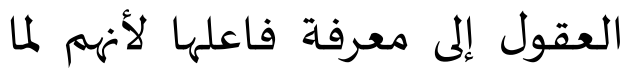

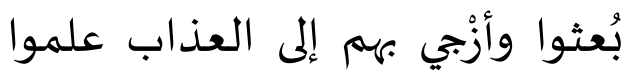
أنه بعثٌ فعَله من أراد تعذيهيهم.

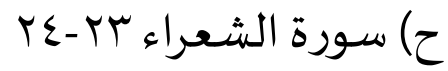
أسلوب الحكيم في هذه الأية

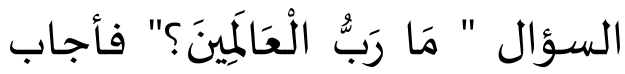

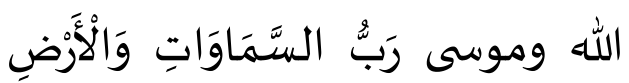

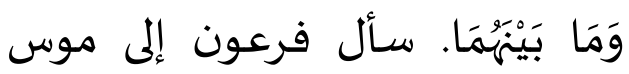
عليه السلام عن الحقيقة الجنس. وأجاب موسى ببين صفة الحقيقة. وهي ببيان خلق الله تعالى وصفتـه. ط) سورة الأحزاب سبان

هذه الآية أسلوب الحكيم من تلقي السائل بغير ما يتطلب، سأل

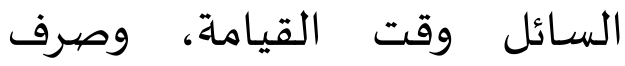
الرسول الله وبارجاع إلى الله. لأن
عرفنا، أن إستفهام "ما" يستفهم غير العقلاء، وقد تكون لتعريف الشيئ وبيان معناه من حيث اللغة كما يقال لك "ما الغضنفر؟ فتقول الأسسد، أو ما البر؟ فتقول القمح". وقد يسأل بها عن الحقيقة الثقال الشيئ كما أقول في ما البلاغة؟ فتقول وصول المعنى إلى القلب بأحسان صورة من اللفظ، وقد

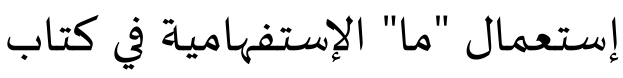
الله تعالى، كقوله تعالى " فَمَا بَالْ

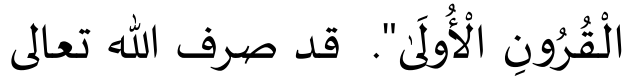
من السؤال فرعون. لأن السؤاله من أمر الغيب، والله تعالى يعلمه المطلق علما. فموسى عليه السلام لا يعلم من هذا العلم. فهذه من آيات أسلوب الحكيم بنوع تلقي السائل من من ائل بما لا تطلب. ز) يس آية بما تهل

أسلوب الحكيم في هذه آية

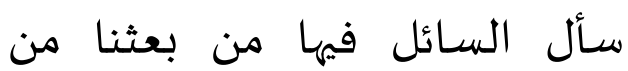
مرقدنا؟ فأجاب الله تعالى فيها آية

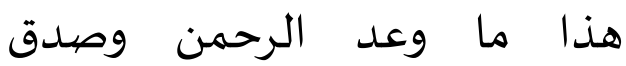
المرسلون، أو سألوا عن الباعث، وعن وكن فكان الجواب بخلاف مرادهم وبغير ما يتطلبون فصرفوا إلى البعث، 
يستخدم حرف الإستفهام "متى" فجوابه عن الزمان والوقت الإستفام. فالسؤال هنا كان يقتضى إجابة بقول أعلم أم لا أعلم وقتها، ولكنها

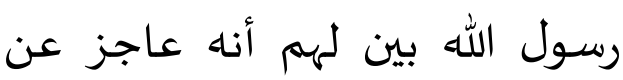
معرفة ما ما ينفعحه وما يضره ـ إن لن الن

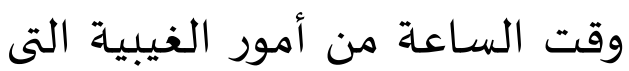

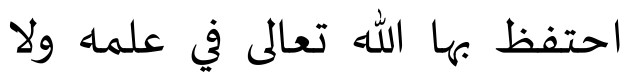
فائدة لنا في معرفتها.

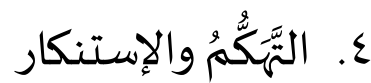

وهو من الأغراض التي قُصدات من إجزاء أسلوب الحكيم في القرآن الكريم، وذلك قصيد الإنكار على الكافرين والمكذبين ما يصدر ودر

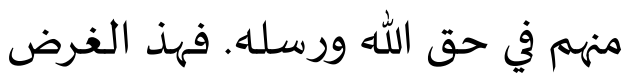

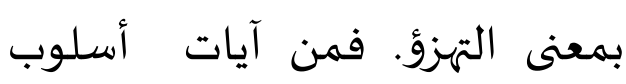

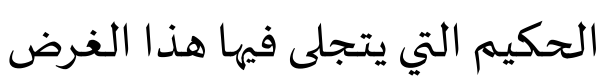
أ) سورة الأنفال 19

أن قريشا كانت تحسب نفسها أهها الأعلى ورسول الله الأسفل وأهنا على الحق ، ورسول الهيا ورسول

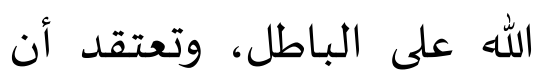
النصر حليفها وأن الله سيمدها باه ، ولذا كانوا يتهكمون بالنبي

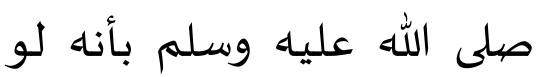

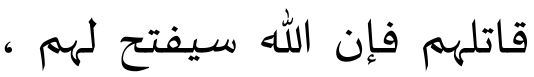

وقت قيام الساعها لا يعلماه الا هو.

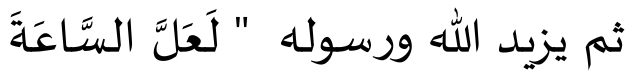

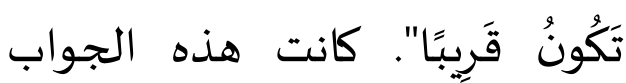

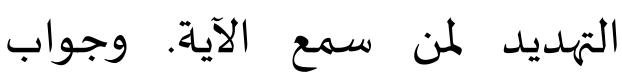
العلمية من هذا السؤال هي وقت وزمان.

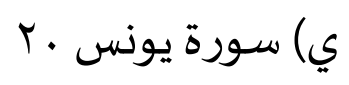

أسلوب الحكيم في هذه الآية

تلقي المخاطَب بغير ما يترقب. إن

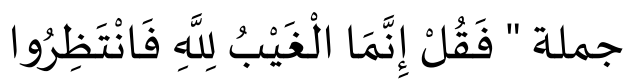

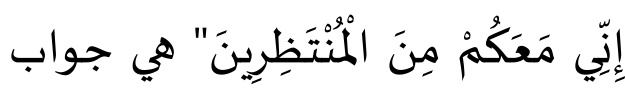
السؤال السائل الذى يريد أن ينظر آية رب العالمين. أمر الله الى رسوله لئه ليقول "إنما الغيب لله". إذا رأينا في

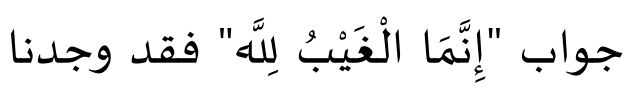
أن هذه الأية هي أسلوب الحكيم من نوع التصريف. صرف الله تعالى من هده

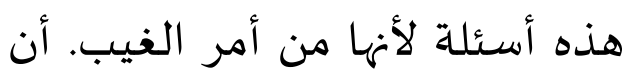
الله أعلم منا ومنكم في كل شيئ وفي كل أمر الغيب. وعلماه مطلق لله. ك) يونس كي اهر الفيب.

نري أن أسلوب الحكيم في

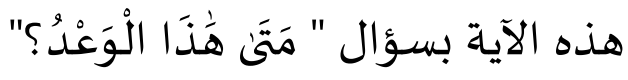
فأمر الله النبي صلى الله عليه وسلم

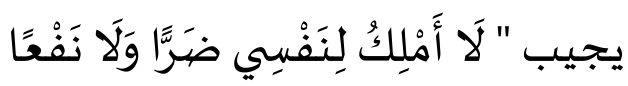

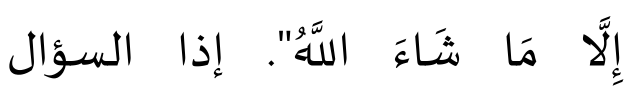


كناية عن انتفاء ما حقة أن

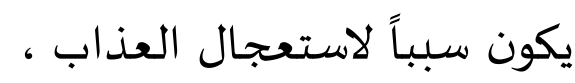

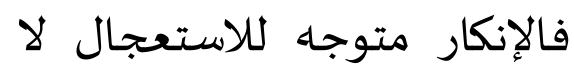
لعلته.ثم أُعقب الإنكار المقتضي متوجيه لإستعال لإن

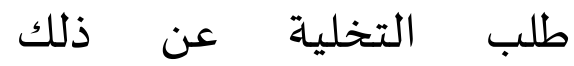
بتحريضهه على الإقلاع عن ذلك

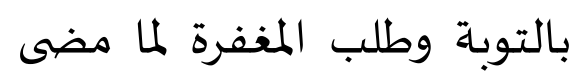
منهم ويرجون أن يرحمهم الله فلا يعذبهم ، وإن كان ما صدر منهم

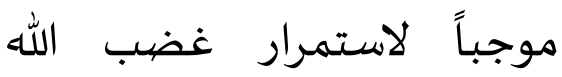
عليهم ، إلا أن الله برحمتـه جعل التائب من الذنب كمن لم يذنب. (ابن عاشور، (YAY:19人). فالاستفهام هنا يثير في النفس التفكير والتخمين فيما هو ابعد من الجواب أو الرد على النهان

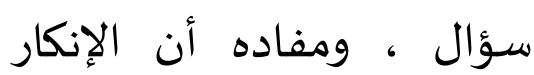
متوجاء للاستعجال ذاته لا لعلته وهذا لأخذهم بجانب العذاب دون جانب الرحمة، وتقديمهم

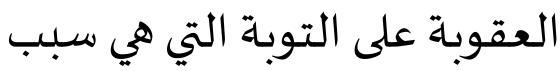
حصول الخيرات التي بشّرهم بها في الدنيا والآخرة لو آمنوا باء. سأل صالح عليه السلام لقوماه، يا قوم لم تستعجلون بالسيئة قبل الحسنة؟ فإنكار
حتى أههم كانوا على يقين من ذلك. قال السيد الكلبي: كان المشركون حين خرجوا إلى النبي

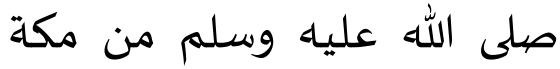
أخذوا بأستار الكعبة، وقالوا: اللهم الصر على الجندين وأهدى الفئتين وأكرم الحزبين وأفضل الفيل الدينين فأنزل الله تعالى هذه الهين ولهن

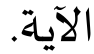
فطلبوا المشركون الفتح من الله في الدعائهم، ولكن الله تلقاهم بغير ما يترقبون ، وخالف مقصودهم ومرادهم ، فلما

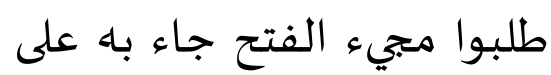
ظاهر كلاههم ، لكن بخلاف

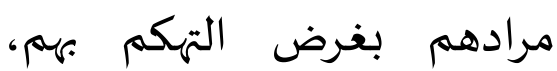
وذلك بأن هذا الفتح عليكم وليس لكم. فإن الفتح للمؤمنين في البدر.

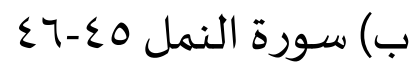
والاستفهام في قوله: "لم تستعجلون" إنكار لأخذهم بجانب العذاب دون جانب الرحمة.وظاهر الاستفهام أنها

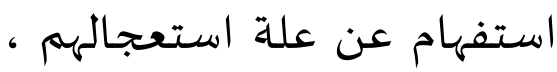
وإنما هو استفهام عن المعلول 
الحكيم من تلقي السائل بغير ما يتطلب إذ هم حين قالوا : أيّان يوم الدين ، أرادوا التهكم

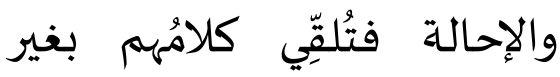
مرادهم. (أبو فطحية: ع ا ـ ب)

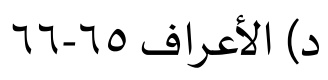

رأينا هذه الآية، وجدنا

جملة الإستفهام أفلا تتقون؟ وهذه السؤال هودا عليه سلام إلى قوماء عاد. فأجابوا إنا لنراك في سفاهة وإنا لنظنك من الكاذبين، أما جواب قوم هودا

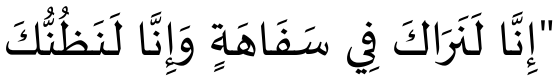

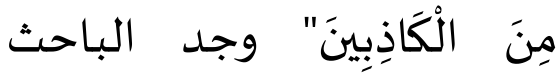
جواب الإستنكاريا والتهكميا. هم وجين يستكرون هودا بجملة لنراك في سفاهة يقولون نبيهم هودا عليه سلام من الكاذبين. وهذه الآية التى تلقى السائل بما يتطلب.

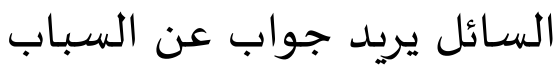
لا يتقين بالله تعالى. فأجابهم ئه بيقولوناه هودا من الكاذبين. إن كان رأينا إلى جمالة يَا

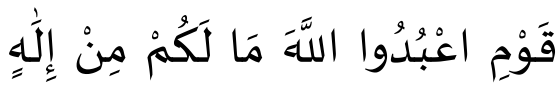

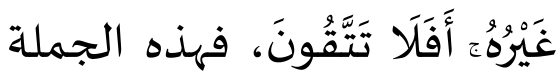
هي جملة لترغيب على قوم هود
قوماه بالجملة الإستنكار، قلوا

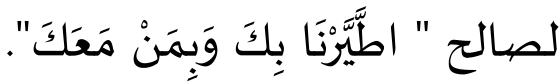
لا يجبوا القوم ثمود عن سباب

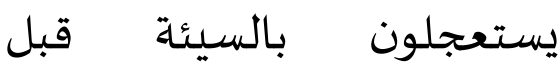

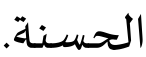
ج) سورة الذاريات ب | - أعانه أسلوب الحكيم في هذد

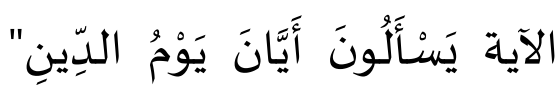

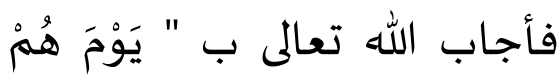

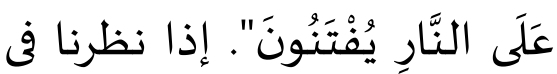
هذه الآية قد عدل عن الجواب. السؤال عن زمان ووقت القيامة. وجواباء عن التهكم إلى الكافرين. "أيّا" اسم استفه الهم إلى الهن زمان فعل وهو في محل نصب مبنيّ على الفتح ، أي متى يوم

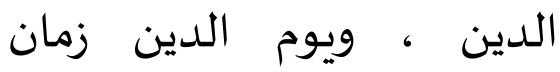

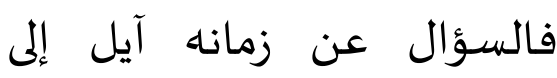
السؤال باعتبار وقوعاء، فالتقدير : أيان وقوع يوم الدين

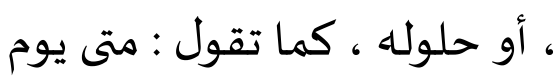
رمَضيان أي متى ثبوتاه لأن أسماء أنماء الزمان حقها أن تقع ظمَّان للأحداث لا للأزمنة. وجملة " يوم ان تقمان هم على النار يفتنون" جواب لسؤالهم جرى على أسلوب 
قد سألوا عن وقت

الوعيد بحرف الإستفهام "متى".

وهذا الإستفهام يدل على زمان

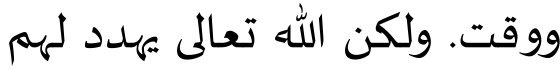

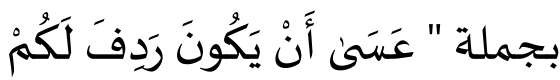
بَعْضُ الَّذِي تَسْتَعْجْلُونَ".

قال إبن عاشـور: مَتَنَ هُذَّا

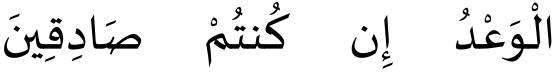
الاستفهام عن زمانه ، وهو استفهام تهكم منهم بقرينة قوله إن كنتم صادقين ـ وأمر الله نبيه

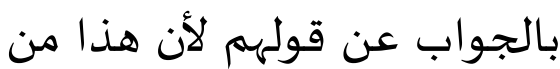
علم الغيب الذي لا يعلمه إلا الله هن هن لهن

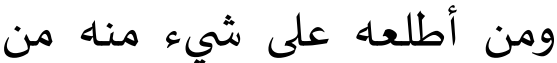
عباده المصطفين. والجواب جار على أسلوب الحكيم بحمل

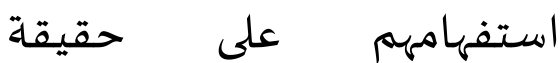
الاستفهام تنبيهاً على أن حقهم أن يسألوا عن وقت الوعيدام تليهيا على ان الوعهيد ليتقدموه بالإيمان (ابن عاشور، .) ( $r V: 1914$

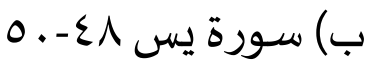

السؤال في هذه الآية "

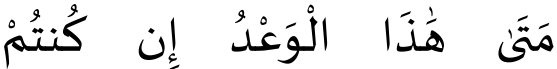
صَادِقِينَ؟" هذا الإستَفهام يدل على زمان ووقت. فهداد الله
عليه السلام. كان هود عليه السلام يدع إلى قوماه ليعبدوا الله تعالى ولا يشركوا باه شيئا. وقد شابهت دعوةٌ هود قومَاه دعوةً نوح قومَهاه في المهم من كلامها :

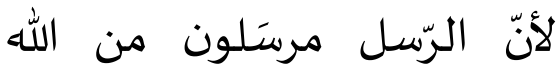
والحكمة من الإرسال واحدة، فلا جرم أن تتشابه دعواتهم. 0. التهديد والترغيب وأما من أغراض بيان أسلوب الحكيم التهديد، اذا سأل السائل عن عذاب النار ويوم الدين فأجاب الله بصفة وأحوالهما بقصيد ليخوفهم من عذاب النار ويوم الدين. وهذه الأوصاف من قبيل

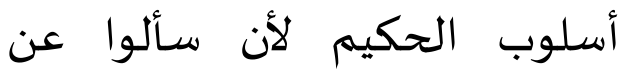
العذاب الذي هددوا باه عن وقتاه ووصفه سؤال استهزاء ، ودعوا الله أن يرسل عليهم عذابا إن كان القرآن حقا، وإن كان يوم القيامة حقا، ثم عذاب النار حقا فأجاب الله تعالى سؤالهم بالتهديدهم، كما قال الله تعالى:

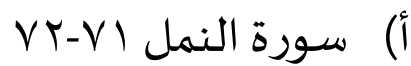


تتوجه هممههم إلى تحقق وقوع الوعد

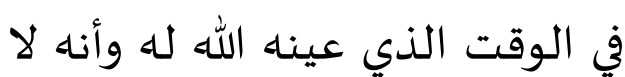
يؤخره شيء ولا يقدماه ، وحسَّن هذا

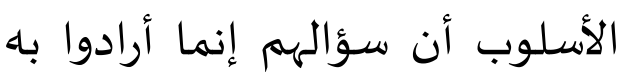
الكناية عن انتفاء وقوعاء. وفي هذا الجواب تعريض بالتهديد فكان

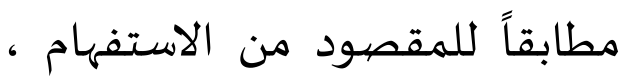
ولذلك زيد في الجواب كلمة " لكم" إشارة إلى أن هذا لمدول الميعاد منصرف إليهم ابتداء (ابن عاشور، إنسارو

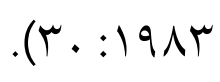$$
\text { د) الإسراء } 01
$$

سأل السائل في هذه الآية هي

" مَتَّى هُوَ؟" اي متى يوم البعث؟. فهدد الله تعالى بجوباه " عَسَنى أَنْ

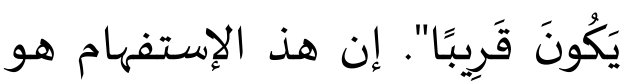
الإستفهام لوقت وزمان في قصيده. قال الطبري : قوله "وَيقُولُونَ مَتى هُوَ"يقول جلّ ثناؤه: ويقولون متى البعث، وفي أيّ حال ووقت لتهول

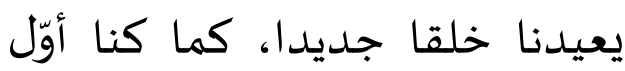
مرّة، قال الله عزّ وجلّ لنبياء: قل لهم جهم يا محمد إذ قالوا لك: متى هو، متى مره هذا البعث الذي تعدنا، عسى أن

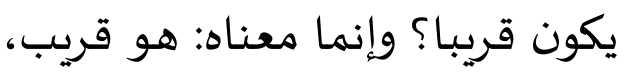

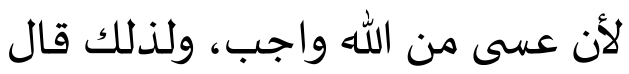

تعالى " مَا يَنظُرُونَ إِلَّا صَيْحَةً

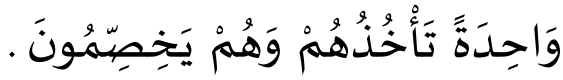

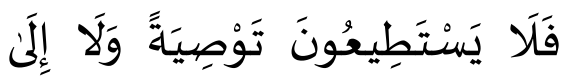

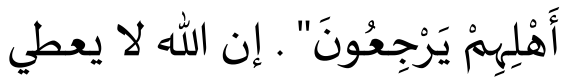
لهم ما يتطلب في السؤالهم. أعرض عن جواب سؤالهم لبيان أن ما أعد الله لهم من العذاب البوابه هو الأجدر واللائق بأن ينتظروه.
أما أسلوب الحكيم في هذه

الآيَة هي إستـفهام "مَتَىَى هُذَا الْوَعْدُ إِنْ

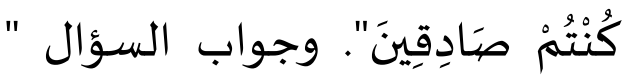

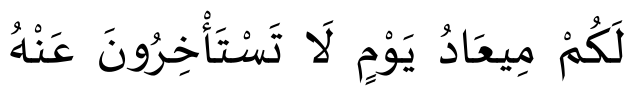

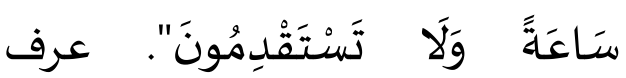
الباحث إستفهام ب"متى" جوبها عن وقت وزمان. لكن الله لا يجيبـاء بوقت

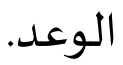

قال إبن عاشور : جملة "قل لكم ميعاد يوم" إلى آخرها مسوقة

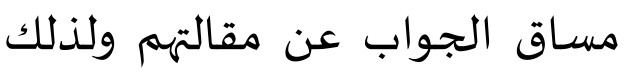
فصلت ولم تعطف ، على طريقة حكاية المحاورات في القرآن ، وهذا الجواب جرى على طريقة أسلوب

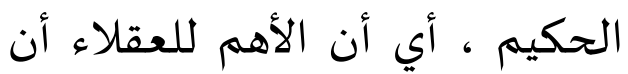


فمراد السائل هو السؤال

عن حقيقة الجبال، وفي السؤال

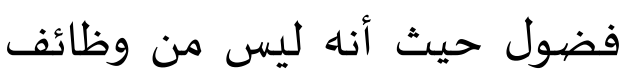
الرسل بيان مثل هذه الأمور، وإن كانوا عالمين بها، ولذلك كان الجواب على ظاهر السؤال مخالفاً لمراد السائل وهو " ينسفها ربي نسفاً.

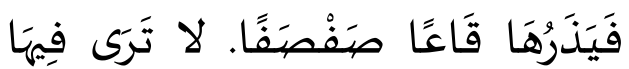

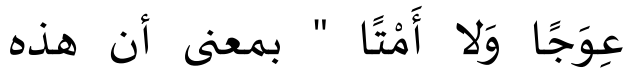
الجبال على عظمتها وضخامتها، ينسفها ربي نسفاً، وهذه من وظائف

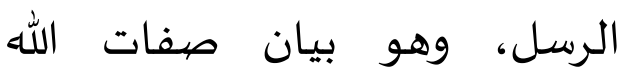
سبحانه. . السـائل يسأل عن الجبال، وهول ماهية وما حقيقة الجبال. ولكن الله مهدد هم بأهوال الجبال في يوم القيامة. هذه الآية هي تلقي السائل بما لا يتطلب، ة جوب السؤال

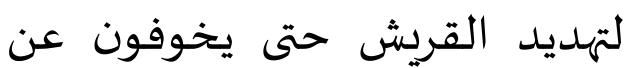

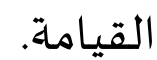

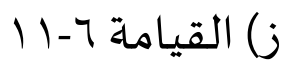
رأى الباحث اعدل في الجواب

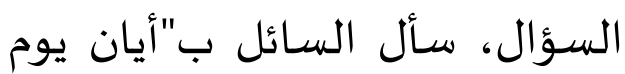
القيامة؟" بمعنى متى وقت يوم لهوان القيامة ؟ فهداد اله تعالى بأهوال يوم

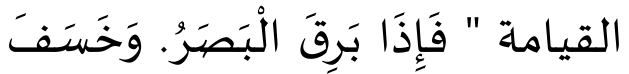

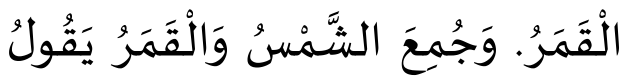

النبيّ صلى الله عليه وسلم ":بُعِثْتُ

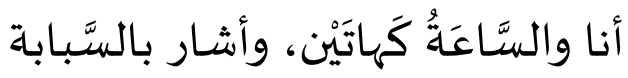
والؤسطَى" ، لأن الله تعالى كان قد أعلماه أنهاه قريب مجيب (أبو جعفر الطبري، ( . . ب). ه) سورة يونس الهبري،

وجملة أحق هو استفهامية معلقة فعل "يستنبئونك" عن العمل وجله في المفعول الثاني، جملة بيان لجملة يستنبئونك" لأنمضمونها هو لهون الاستثناء. والضيمير يجوز كونه مبتداء، و"أحق" خبر مقدم. فهذا جواب لهو التهديد إلى قوم الكافرين.

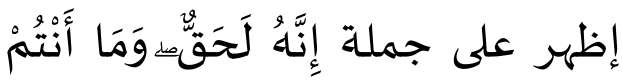

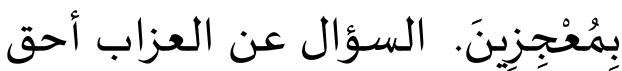

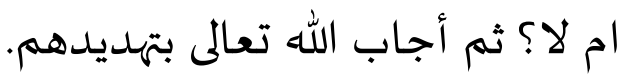
و"إي" بكسرة الهمذة، حروف جواب إن لتحقيق ما تضمينه السؤال سائل، فهو مرادف "نعم"، ولكن من من تهينه خصائص هذا الحرف أنه لا يقع إلا هرن وبعد القسم. ويستنبئونك هو

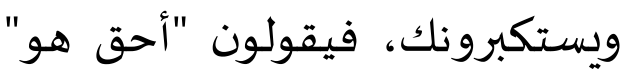
وهو استفهام على جهاة الإنكار والإستهزاء. (الخوارزمي: 9. . . ب) و) طه 1.0 
تحقيق الحكمة، إظهار القدرة على

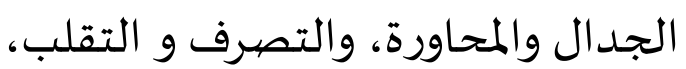

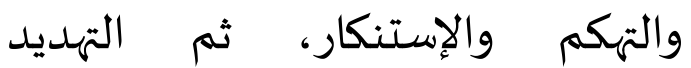
والترغيب.

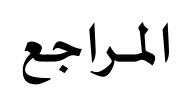

إبراهيم، سيد قطب. 11 .r. في ظلال

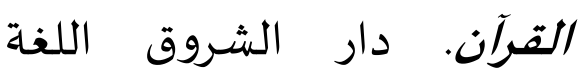

$$
\text { العزبية . }
$$

إبن كثير، عماد الدين. 1999. تفسير الدربه القرآن العظيم. بيرت: دار الرين.

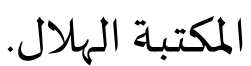

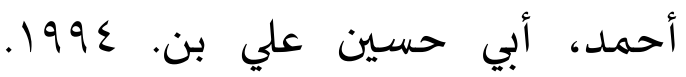

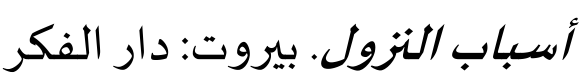
الجرجاني، علي بن محمد بن علي الزين الشريف. التعريفات. بيروت : دار

$$
\text { الكتب العلمياة. }
$$

الجرجاني، عبد القاهر بن عبد الرحمن.

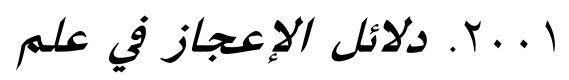

$$
\text { المعاني. دار الكتب العلمياة. }
$$

الخوارزمي، أبي القاسم جار الله محمود

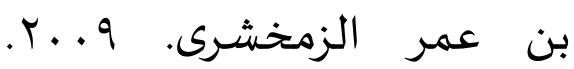
الكشاف عن الحقائق التنزيل و عيون العقاويل في وجوه التأويل. بيرت : دار المعرفة.

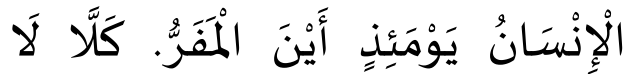
وَزَرَ".هذه الآيـة هي تلقي السـائل بهم لا يتطلب، السائل يطلب وقت القيامة والجوب حالتها.

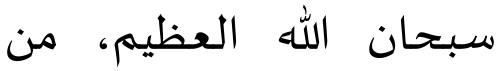
هذه آية نعرف قيمة هذا الأسلوب الذي استعمله القرآن الكريم، لما له هده اله من حُسنس في التحسين وعمق في المعني،و واسع في التفسير ولطف في الألفظ، قصيد التنبيه عن اللائق والأهم بتعليم الحقائق.

\section{الخلاصة}

وقد وجد الباحث في القرآن الكريم آ آية تستخدم أسلوب الحكيم حيث أن الإجابات مما لم يترقباه السائل. استعمال أسلوب الحكيم في القرأن الكريم كان مراعة لعدة جوانب في السائلين، من جانب الاجتماعية أو أو

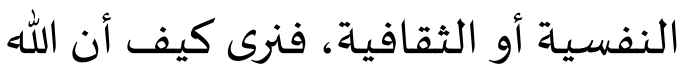

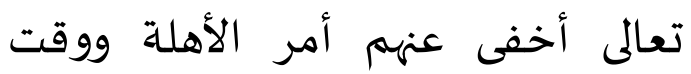
الساعة مراعاة لمستواى السائلين الفكري، وكيف كان طريقا للجدال

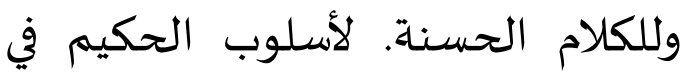
القرآن الكريم أغراض متعددة، منها:

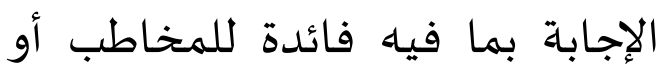


الشيرازي، أحمد أمين. ... . ا. البليغ في

المعاني والبيان والبديع. إيران:

مؤسسة النشر الإسلامي.

الضيناوي، محمد أمين. ع ا.Y. معين الإسي

الطالب في عاوم البلاغة. بيروت:

$$
\text { دارالكتب العلمية. }
$$

الطبري، محمد بن جرير بن يزيد بن

كثير بن غالب الآملي أبو جعفر.

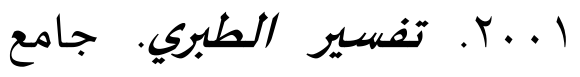

البيان عن تأويل آي القرآن.

$$
\text { القاهرة: مكتبة إبن تيمية. }
$$

القطان، مناع. 1919 ـ مباحث في علوم

القرآن. بيروت: دار الرشيد

$$
\text { القرآن الحكيم. الرياض. }
$$

القرطبي، حمد بن أحمد بن أبي بكر بن

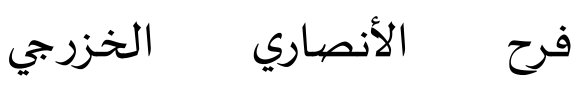

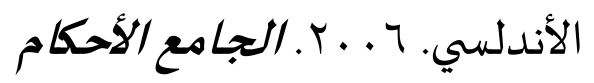

القرآن. مؤسسة الرسالة.

العطيق، عبد العزيز. rا .r. في بلاغة العالة

العربية علم البديع. بيروت: دار بلار

$$
\text { النهضة العربية. }
$$

النيسابوري، أبي الحسن علي بن أحمد العداء

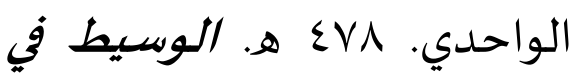

تفسير القرآن المججيد. بيروت:

$$
\text { دار الكتاب العلمية. }
$$

الدمشقي، إسماعيل بن عمر بن كثير

القرشي. 1999. تفسير القرآن

العظيم، دار طيبة للنشر الفرئ

والتوزع.

الدين، محمود شكري الألوسي

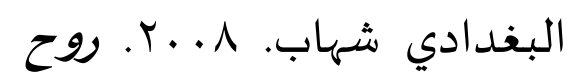

المعاني في تضسير القرآن العظيم

والسبع المثاني. تصوير دار إحيار

$$
\text { التراث العربي. }
$$

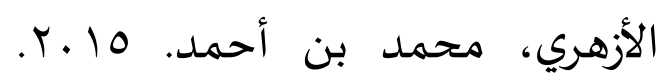

تهذيب اللغة. بيروت: دار إحياء

$$
\text { التراث العربي. }
$$

الرافعي، مصطفى صادق. 10.r.

إعدجاز القرآن و البلاغة النبوية.

$$
\text { دار الكتاب العربي. }
$$

السعدي، عبد الرحمن بن ناصر.

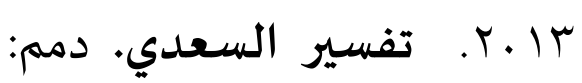

$$
\text { دار ابن الجوز. }
$$

الشافعي،أحمد بن علي بن حجر أبو اجورن

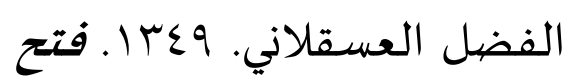

الباري شرح صحيح البخاري.

ترقيم : محمد فؤاد عبد الباقي.

إخراج وتصحيح : محب الدين : معمدواد

الخطيب. تعليق : عبد العزيز بن

عبد الله بن باز. بيروت: دار :عليد

المعرفة. 


$$
\begin{aligned}
& \text { الباقلاني وأثره في منهج } \\
& \text { الدراسات الاستشراقية }
\end{aligned}
$$

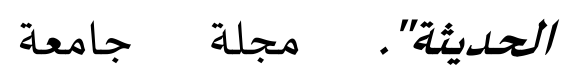

$$
\begin{aligned}
& \text { حسيبة بن علي الشلف. }
\end{aligned}
$$

مبدوعة، طوطاوي زوليخة زوجة.

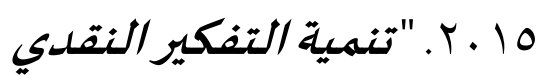

في التعليم". كلية العلوم

الانسانية و الاجتماعية جامعة

$$
\text { تيزي وزو، منتدباة بالمدرسة }
$$

الوطنية التحضيرية لدراسات

$$
\text { مهندس. }
$$

محمد محمد أبو موسي. 199V. من

أسرار التعبيلا القرآني.

$$
\text { القاهرة: مكتبة هبة. }
$$

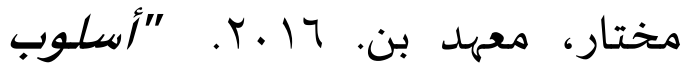

الإلتفات و دلالته في القرآن

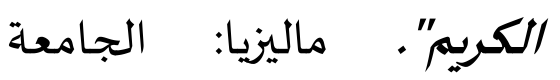

$$
\text { الإسلامية العالية . مالينا. }
$$

هارون، طارق فاروق عبدالله. IV.r. "للقرأن الكريم وبناء الحضرة

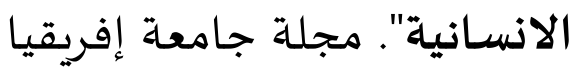

$$
\text { العالمية. }
$$

$\mathrm{Al}$ adnani, Abu Fathiyah. 2014. Kita berada di akbir zaman. Surakarta: Granada media utama.

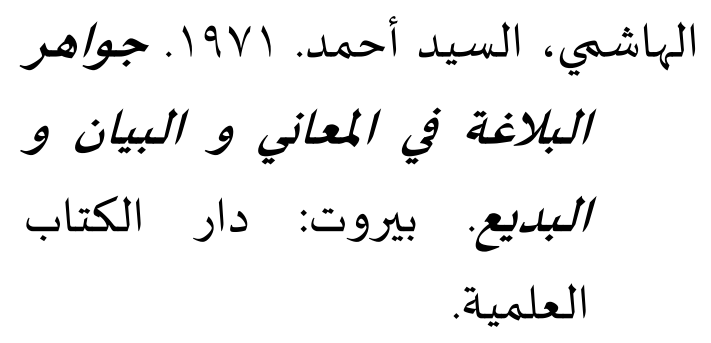

بازمبول، محمد بن عمر بن سالم.

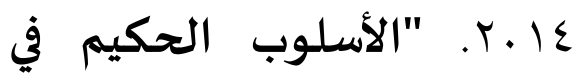

$$
\text { الحديث النبوي". مجلة كلية الديلوب }
$$$$
\text { الدعوة وأصول الدين قسم الديوي مجدية }
$$

$$
\text { الكتاب والسنة. جامعة أم القرى الدعول واهئ }
$$

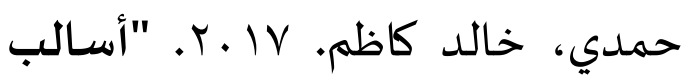

البديع في نهج البلاغة (دراسـة

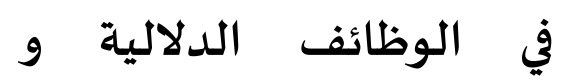

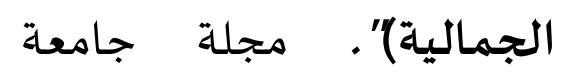

الكوفة قسم اللغة العزبية.

سلامة، محمد حسين. ا . . T. الإعدجاز

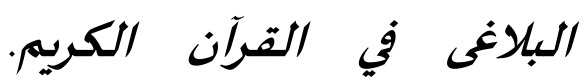

القاهرة: دار الأفاق العربية.

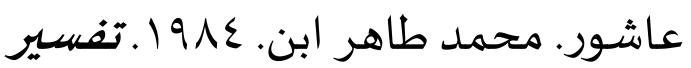

التحرير و التنوير. تونس: دار

$$
\text { التونيسية للنشر. }
$$

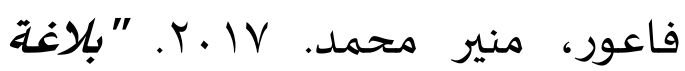

الأجوابة المسككة أسلوب

الحكيم نموذجا". دمشق: المشئه

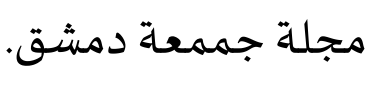

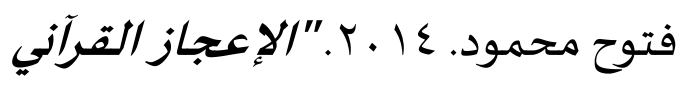

من المنظور البلاغي عند

89| Ferki Ahmad Marlion, Ahmad Dardiri 